\title{
Towards a non-arbitrary account of affricates and affrication
}

\section{Glossa}

a journal of general linguistics

SPECIAL COLLECTION: GLOWING PAPERS

\section{MARKUS A. PÖCHTRAGER (i)}

\section{] $\mathrm{u}[$ ubiquity press}

\footnotetext{
Abstract

This article presents a novel account of affricates/affrication and palatalisation (and their interrelationship) in Japanese, Brazilian Portuguese, and Québec French, as well as English and Korean, within a further development of Government Phonology. Several properties of those two phenomena follow from independently established assumptions of the theory, in particular on the internal structure of obstruents, the nature of coronality, the representation of vowel height, and the asymmetric behaviour of the elements $\mathbf{I}$ and $\mathbf{U}$. Stopness is argued to be encoded structurally, as a relationship between two positions, and that relationship is broken up by the palatalising effect of the element $\mathbf{I}$, the result of which is affrication. The conditions under which this happens fall in line with well-known properties of the triggers.
}

CORRESPONDING AUTHOR:

\section{Markus A. Pöchtrager}

University of Vienna, Sensengasse 3a, 1090 Vienna, Austria

markus.poechtrager@univie.ac.at

KEYWORDS:

affrication; palatalisation; structure; spreading; Government Phonology

TO CITE THIS ARTICLE: Pöchtrager, Markus A. 2021 Towards a non-arbitrary account of affricates and affrication. Glossa: a journal of general linguistics 6(1): 61. 1-31. DOI: https://doi. org/10.5334/gjgl.1116 


\section{Background}

Articulatorily, affricates involve a complete closure with a fricative/delayed (or also nasal) release (Lin 2011), as for example at both the beginning and the end of English church [ 33 t $\left.\int\right]$. But sound by itself will not tell the whole story, of course. Beer (the drink) is as good a place as any to start the discussion. Beer mugs in Austria and Germany often have the little rhyme in (1) on them:

$$
\begin{array}{ll}
\text { Hopfen und Malz, } & \text { 'Hops and barley,' } \\
\text { Gott erhalt's. } & \text { 'may god preserve it.' }
\end{array}
$$

Both lines end in [ts], i.e. a complete closure with a fricative release. Yet while in the first we are dealing with a single consonant (a "true" affricate) in mono-morphemic Malz, we have a sequence of stop plus fricative across two morphemes in erhalt's. The phonetic identity is an accident here, and phonological theory needs to go beyond the phonetic outcome and provide an answer to what the accurate phonological representation of an affricate is from which distributional and behavioural facts could then be derived.

The analysis of affricates, however, is a contested area. One aspect where there does seem to be agreement is their monosegmental status. In Turkish, for example, affricates pattern together with single consonants in terms of their distribution, and not with clusters. Consider the examples from word-initial position as in (2), with transcription of initial consonant(s) only.

\begin{tabular}{l}
\multicolumn{3}{c}{ Turkish: Word-initial position } \\
$\begin{array}{lll}\text { a. } & \text { top 'ball } & {[\mathrm{t}]} \\
\text { b. } & \text { son 'end' } & {[\mathrm{s}]} \\
\text { c. } & \text { tren 'train' } & {[\mathrm{tir}]} \\
\text { d. } & \text { spor 'sports' } & {[\mathrm{suup}]} \\
\text { e. can 'soul' } & {[\mathrm{d} 3]} \\
\text { f. } & \text { çöp 'garbage' } & [\mathrm{t}]]\end{array}$
\end{tabular}

Affricates occur while clusters are barred. Turkish does not allow for initial branching onsets and breaks them up in loans (2c-d), but has no problem with affricates (2e-f), which therefore can be taken as single objects. Besides the monosegmental status, there is disagreement, as summarised in detail in a recent overview by Lin (2011). The controversy centres around two main questions: (i) How do affricates differ from fricatives/stops, given that they seem to pattern with/combine aspects of both? (ii) Is there internal structure to affricates, in the sense that they contain two discernible, phonologically relevant parts?

As for the first question, depending on the phenomenon and the particular analysis proposed, either grouping (affricates with stops or with fricatives) has been argued for. Turkish stops and affricates undergo (syllable) final devoicing (Lees 1961; Lewis 1967; Underhill 1976; Kopkall1 1993; Göksel \& Kerslake 2005; Balcı 2006; Erguvanlı Taylan 2015), while fricatives do not (3), setting the former two apart from the latter. The selection of the English plural suffix in (4), however, seems to treat affricates like fricatives and unlike stops.
Turkish: Affricates like stops

$\begin{array}{lllllll}\text { a. } & \text { tad- }- \text { 'its taste' } & {[\mathrm{d}]} & \text { tat 'taste' } & {[\mathrm{t}]} & \text { devoicing } \\ \text { b. } & \text { tac- } \iota & \text { 'his crown' } & {[\mathrm{d} 3]} & \text { taç 'crown' } & {[\mathrm{t}]} & \text { devoicing } \\ \text { c. } & y a z-\iota & \text { 'writ' } & {[\mathrm{z}]} & \text { yaz! 'write' } & {[\mathrm{z}]} & \text { no devoicing }\end{array}$

(4) English: Affricates like fricatives
a. hat-s $[\mathrm{t}-\mathrm{s}]$ no epenthesis
b. hatch-es [t $\int$-iz] epenthesis
c. hash-es [f-iz] epenthesis

English also allows for an alternative analysis, leading straight to the second question raised above: Is there internal structure to affricates? If so, English epenthesis could be restated such that the suffix only sees material to its immediate left, i.e. the fricative [ $]$ ] in both hatch and hash. Any material further left, such as the stop portion of the affricate, would simply be irrelevant. Such edge effects often serve as evidence for internal (sequential) structure in affricates. Turkish devoicing could be a potential counterargument, though: Assuming that the word or syllable 
boundary acts as the trigger, devoicing ignores the fricative portion of an affricate (as it would a fricative) and thus treats stops and affricates alike. As a more general argument against internal structure, Clements (1999) expresses concern about overgeneration: Positing internal structure (and potentially independent halves) raises the question why homorganicity is enforced in an affricate, instead of allowing independent specification of each member.

Trying to avoid these pitfalls, in this article I intend to propose a formal representation for affricates whose structure and behaviour falls out easily from previous work in Government Phonology (GP), in particular the offspring labelled GP 2.0. (References in section 3.1.) In that theory, stops are objects where parts remain unpronounced by a relationship called control. I argue that in affricates this relationship is lacking, giving rise to the fricative portion of an affricate. While this sounds trivial, this "exposure" of a previously controlled (empty) position allows us to derive a number of properties of affricates, and in addition fits in well with the modelling of other phonological phenomena, such as vowel reduction, asymmetries in vowel harmony, lenition, and palatalisation (see below). Several strands of research come together in this account of affricates. To the extent that I take affricates as an intermediate category between fricatives and stops, I align myself with the proposals in Chomsky \& Halle (1968), LaCharité (1993), Rubach (1994), Kim (1997), Clements (1999), Kehrein (2002), and Tifrit \& Voeltzel (2016), who, in various ways, also take affricates as a subtype of stops. (Many of them rely on the feature [strident], which is not part of GP.)

In order to better understand what affricates are, we will look at cases where their distribution is governed by phonological context. Palatalisation is a typical source of affricates, and so we will look at what the interaction of palatalisation can teach us about affricates. The literature on palatalisation is extensive, cf. Bhat (1978), Bateman (2011), Kochetov (2011), and Krämer \& Urek (2016) for general overviews, and Chen (1973; 1996), Foley (1977), Sagey (1990), Lahiri \& Evers (1991), Clements \& Hume (1995), Kochetov (2002), Hall \& Hamann (2006), Bateman (2007) for individual proposals, as well as Nasukawa (2016), Tifrit \& Voeltzel (2016) for recent contributions within GP (2.0). There is an immediate problem with palatalisation, though, in that it is often very broadly construed and covers a multitude of different operations, as also pointed out by Bateman (2007: 1), Bateman (2011: 589f), Krämer \& Urek (2016: 2) etc. For example, Bateman (2011) requires a high/front vocoid as a trigger, while Kochetov (2002) and Bateman (2007) do not. The definition in Bateman (2007: 5) would exclude $t \rightarrow s$ as a palatalisation, Kochetov (2002) would not. Foley (1977) and Bhat (1978) look at a mixture of synchronic and diachronic cases and do not separate phonological from morphological conditioning, while Bateman (2007) takes great pains to keep all those factors apart etc. The list could be continued. As a result, we will have to draw the line somewhere. We will draw it very tight and limit ourselves to a subset of patterns with coronals as targets of affrication, the reasons for which will be explained in a moment.

In terms of data we will focus on affrication patterns in three languages in detail: Japanese (Yoshida 2001; Labrune 2012; Pintér 2015), certain varieties of Brazilian Portuguese (Mateus \& d'Andrade 2000; Cristófaro-Silva 2003), as well as Québec French (Walker 1984). There are several reasons for choosing these languages: (i) They display complex affrication patterns that are similar to each other and yet differ in small but crucial details. In particular, these languages illustrate well the implicational hierarchies that have been established in work on palatalisation (cf section 2). (ii) Brazilian Portuguese and Québec French differ minimally in that affrication occurs independently of palatalisation in the latter, allowing us to tease apart the factors responsible for each of the two. (iii) All three languages target coronals, which are the most common targets of palatalisation (Bateman 2007: 21), pace Chen (1973), so it seems reasonable to start there. (iv) The affrication patterns are regular and of a synchronic nature, without morphological conditioning. It is not uncommon for the literature on palatalisation to treat synchronic and diachronic patterns alike (as noted before), making it harder to come to an understanding of what a phonological process can be (qua manipulation of phonological representations in the speaker's mind) instead of what sound change can achieve (qua transmission via externalisation).

Remaining on that last point, a word about non-arbitrariness (as in the title): Non-arbitrariness has been one of the non-negotiable core assumptions of GP since its inception. This is embodied in the Non-Arbitrariness Principle (NAP), which demands that there be a connection between 
target and trigger. This requirement is not met in rewrite rules of the shape $A \rightarrow B / C \_\ldots$ (in whichever guise they appear), since no connection is required between structural description and structural change. Autosegmental Phonology (Goldsmith 1976) remedied this in part, by expressing many phonological events by spreading, thus guaranteeing the required link: Spreading of a property $\mathrm{P}$ from $\alpha$ to $\beta$ not only explains why $\beta$ acquires $\mathrm{P}$, but also why it acquires it in the context of $\alpha$; a non-arbitrary link is established. The emphasis that GP puts on the NAP is not an exercise in self-restriction, but is rooted in the desire to create a theory rich in empirical content of what a possible phonological process can be. The NAP operates in tandem with the Minimality Hypothesis (MH) (Kaye 1992b; 1995), which complements the NAP (Pöchtrager \& Kaye 2011; Pöchtrager 2014). The MH demands that processes apply whenever their conditions are met. This excludes exceptions, (anything equivalent to) extrinsic rule ordering and derived environment effects in truly phonological processes.

This search for a non-arbitrary link between process and environment has also motivated the choice of languages here. Given that the affrication patterns in those languages conform to the $\mathrm{MH}$ and depend on their phonological environment, phonological theory should provide such a non-arbitrary link. This is what this article attempts to contribute. This also takes us back to why we focus on affrication of coronals. In his discussion of affrication in Japanese, Yoshida (2001) includes velars, since in some Japanese dialects [ki] has gone to [t]i]. (This is not what we find in the standard, which we are concerned with here.) A change from [ki] to [t $\left.\int \mathrm{i}\right]$ would be excluded by the theory as a phonological process on general grounds, as it is not expressible in a non-arbitrary fashion: There is a local source for the palatality of [t $\left.\int\right]$ (the following vowel) but not for its coronality. ${ }^{1}$ Accordingly, while common as a diachronic change, it does not qualify as phonological (Pöchtrager \& Kaye 2011; Pöchtrager 2014). Sound change has left behind many alternations between [k t f], e.g. in Italian (Krämer 2009) and Polish (Gussmann 2007), but our prediction is that they are typically idiosyncratic and exception-prone. This is borne out: Italian $\operatorname{di}[\mathrm{k}] \mathrm{o} / \operatorname{di}\left[\mathrm{t} \int\right] i$ 'I/you say' but evo[k]o/evo[k]i 'I/you evoke'; the latter being in fact the regular pattern, cf. also Dressler (1985: Chapters 6-7) for a detailed comparison of the two languages. To be sure, there are cases of affrication (and coronalisation) of velars in the literature that some would deem phonological. Bateman (2007: 10) takes as phonological what "occurs across the board, which is understood as allophony" and gives several examples of languages where her definition of phonological conditioning is met in cases of velar affrication/coronalisation. But allophony is not the same as conformity to the NAP (because we could be dealing with extrinsic allophones) and so each case would have to be looked at separately. Bateman (2007: 11) gives Nkore-Kiga as a language with phonological affrication/coronalisation of velars, but the characterisation in Taylor (1985: 112) is that of an (on-going) sound change; and even the varieties that have most fully realised it still have derived contrasts. Another example listed, Breton (Bateman 2007: 306), is not quite clear, either, with Dressler (1972: Chapter 4) arguing that palatalisation is morphonological. This is not to denigrate the excellent work of Bateman, but just to show that care has to be taken what is actually compared. This paper adheres closely to the NAP by trying to link a characterisation of affrication with the context it occurs in, and to the $\mathrm{MH}$ by looking at affrication patterns that are exceptionless and phonologically conditioned. Certain assumptions, such as a rather rich internal structure for stops and coronals (section 3), might seem surprising at first, but are in fact motivated by the NAP. Of course, this will only be appreciated if phonology is not simply seen as a system that allows random operations to take place.

Rather than giving an analysis of every detail of affrication in Japanese, Brazilian Portuguese and Québec French, we shall focus on the key cases that must form the foundation of any analysis of affrication. We shall see that as a side effect, the complex changes of non-prevocalic consonants in Korean also find a natural explanation, as discussed in a separate section. Additionally, we will make a quick detour into English, where coronal stops also play an important role, viz. for tapping/glottalisation. This allows us to narrow down the contribution of coronality and come up with some generalisation of where lenition occurs. Lastly, asymmetries in the context 
triggering affrication will also be shown to be derivable from a more general theory of the internal structure of vowels.

\section{Data}

The chart in (5) gives a condensed overview of the phenomena to be discussed in this article.

\begin{tabular}{|c|c|c|c|c|c|c|c|c|c|c|c|c|}
\hline \multirow[t]{2}{*}{ Japanese } & a. & $\mathrm{t}$ & + & $\mathrm{i}$ & $\rightarrow$ & $\mathrm{t} \int \mathrm{i}$ & b. & $\mathrm{t}$ & + & u & $\rightarrow$ & tsur \\
\hline & & $\mathrm{S}$ & + & $\mathrm{i}$ & $\rightarrow$ & $\int \mathrm{i}$ & & $\mathrm{S}$ & + & u & $=$ & suI \\
\hline \multirow[t]{2}{*}{ Brazilian Portuguese } & c. & $\mathrm{t}$ & + & $\mathrm{i}$ & $\rightarrow$ & $\mathrm{t} \int \mathrm{i}$ & d. & $\mathrm{t}$ & + & $\mathrm{u}$ & $=$ & tu \\
\hline & & $\mathrm{S}$ & + & $\mathrm{i}$ & $=$ & si & & $\mathrm{S}$ & + & $\mathrm{u}$ & $=$ & su \\
\hline \multirow[t]{2}{*}{ Québec French } & e. & $\mathrm{t}$ & + & $\mathrm{i}$ & $\rightarrow$ & tsi & f. & $\mathrm{t}$ & + & $\mathrm{u}$ & $=$ & tu \\
\hline & & $\mathrm{S}$ & + & $\mathrm{i}$ & $=$ & si & & $\mathrm{S}$ & + & $\mathrm{u}$ & $=$ & su \\
\hline
\end{tabular}

Vertically, the chart is organised by language and affected consonant, and horizontally by the triggering vowel. The non-syllabic counterparts of those vowels (i.e. glides) act as triggers as well, which is not reflected in the chart for the sake of simplicity, but which will be addressed in section 6 . The consonants that are affected are all coronal obstruents. The chart only gives [t] and $[\mathrm{s}]$ on the understanding that their voiced counterparts are affected in the same fashion. ${ }^{2}$ The pluses in (5) do not refer to morpheme breaks; an entry such as " $t+i \rightarrow t \int i$ " is simply to be read as "[t] followed by [i] is affricated and palatalised, yielding [t $\left.\int \mathrm{i}\right]$ ". All cases would be palatalisations in the terminology of Kochetov (2011: 1670-1673), though (5b, e) would not qualify for Bateman (2007). ${ }^{3}$ We will now break down this complex state of affairs language by language and, afterwards, summarise the main points that emerge from the chart.

Japanese (5a-b) is the most complex representative. Alveolar stops are affricated and palatalised before high front vowels and glides, while fricatives are only palatalised (5a). ${ }^{4}$ Before back vowels we also find affrication of stops (5b), but no palatalisation. ${ }^{5}$ Fricatives stay unaffected here. Verb stems ending in [t] and [s] serve to illustrate these points:

(6)

\section{Japanese}
a. tat- "stand":
ta[t] anai 'does not stand PLAIN'
$t a[t]$ imasu 'stand NEUTRAL-POL. - $t a[t s] u$ stand PLAIN'

b. hanas- 'speak':

hana[s]anai does not speak PLAIN'

hana[J]imasu 'speak NEUTRAL-POL. — hana[s]u 'speak PLAIN'

Brazilian Portuguese $(5 c-d)$ shows fewer alternations than Japanese: Again, alveolar stops are affricated and palatalised before high front vowels and glides; but this time fricatives are unaffected (5c). Back vowels and glides do not trigger any change at all (5d).

$$
\begin{aligned}
& \text { Brazilian Portuguese } \\
& \text { a. bate ['bat]i] 's/he beats - bato ['batu] 'I beat' } \\
& \text { b. cose ['kosi] 's/he sows' - coso ['kosu] 'I sow' }
\end{aligned}
$$

Finally, consider Québec French (5e-f), which differs markedly from the other two languages since stops are affricated but not palatalised (5e). Affrication can be had without palatalisation,

2 There is a complication in the case of Japanese [z] which is often in free variation with [dz]. Since both undergo palatalisation in the same context, nothing hinges on this for our purposes and we will ignore it here. The reader is referred to Labrune (2012: 64-66) for further details. Also, Hall \& Hamann (2006) argue for an implicational relationship such that voiced stops are only affected by assibilation if voiceless ones are. Again, this is immaterial for us, since both series are affected in the languages under consideration.

3 A reviewer points out that there is also secondary palatalisation, e.g. in Japanese (Chen 1996: 29-32). Since this does not lead to affrication I will leave it aside here.

4 Japanese affricates are alveolo-palatal [tc], [dz] rather than palatoalveolar $[\mathrm{t} f],\left[\mathrm{d}_{3}\right]$ as in Brazilian Portuguese or English. Many transcriptions ignore this and so will we for the time being, but the issue will be addressed in section 4.5

5 The identity of the high back vowel in Japanese will be discussed in section 6.3. 
as a result of which the changes in (5e) in Québec French parallel those before back vowels in Japanese (5b). All front high vowels and glides trigger affrication, including the front high rounded ones which the other two languages lack. As in Brazilian Portuguese, the fricatives in (5e) are unchanged. And again, nothing happens before back vowels (5f).

$$
\begin{aligned}
& \text { Québec French } \\
& \text { a. [ts] before }[\mathrm{i} / \mathrm{I}] \text { : tigre 'tiger', petit(e) 'small M/F' } \\
& \text { b. [ts] before }[\mathrm{y} / \mathrm{Y}] \text { : tube 'tube', coutume 'custom' } \\
& \text { c. [t] elsewhere: tout(e) 'all M/F', toucher 'to touch }
\end{aligned}
$$

Summing up the discussion so far, the following five points stand out and will be addressed in the course of this article:

Firstly, why are only coronals affected? Labial obstruents, say, are never targeted by affrication and palatalisation in those languages.

Secondly, what is special about high vowels (and glides) that they should trigger affrication/ palatalisation? Palatalisation could easily be modelled as the spreading of the (frontness) element I, but that element is present in other front vowels as well, and yet they fail to trigger palatalisation. Furthermore, as Québec French and Japanese make clear, palatalisation is not a necessary condition for affrication.

Thirdly, connected to the previous point, how do affricates differ from stops and/or fricatives? Why do stops undergo a change in manner and fricatives do not, while both can undergo a change in place?

Fourthly, what, if any, is the connection between affrication and palatalisation, in particular since the former can occur without the latter (in Québec French)?

Fifthly and finally, why are front high vowels/glides more likely to trigger affrication (5a, c, e) than back high vowels (5f)?

The sample size is small here, since we are looking at only three languages (and two more as we proceed), but all the asymmetries we see are well-known in the literature (cf. references in section 1). They feature prominently in the works of Chen (1973) and Foley (1977), where those hierarchies are taken as basic and all-permeating in phonological theory; but they do inform other accounts as well.

We will now move on to the theoretical assumptions underlying the present account.

\section{Government Phonology 2.0}

\subsection{From Government Phonology 1.x to 2.0}

Government Phonology (GP) 2.0, an offspring of "classic" Government Phonology (Kaye, Lowenstamm \& Vergnaud 1985; 1990; Charette 1990; 1991; Kaye 1990a; Harris 1994), owes its existence amongst other reasons to the assumption that certain properties commonly expressed melodically are better treated as structural. A simple example is furnished by the element $\mathbf{H}$, which in earlier versions represented voicelessness in consonants. English $d$ and $t$ would differ (privatively) in that the latter, but not the former, contained H. However, such a difference in the internal makeup of melodic primes does not explain why vowels before lenis consonants like $d$ are systematically longer than before $t$, e.g. bid vs bit for a lexically short (lax) vowel and bead vs beat for a lexically long (tense) vowel. ${ }^{6}$ Pöchtrager (2006b) argued that the fortis/lenis contrast had better be represented structurally, with lenis consonants containing an empty position that could be "borrowed" by a preceding vowel, while fortis consonants had all their positions used up. In a sense then, English [d] would be the shorter version of [t], and the vowel preceding would adapt in length. Such a reinterpretation of the facts as a trade-off between vowel and consonant allows for a non-arbitrary expression of the phenomenon, in

6 The phenomenon commonly runs under the name of pre-fortis clipping and is considered "non-phonemic" in nature by the mainstream, hence of lesser importance for phonologists. Yet Estonian overlength (usually considered phonemic) shows striking similarities to English and has to be accounted for somehow in phonological theory. GP, in the original spirit of Generative Phonology, does not uphold the phoneme/allophone distinction (for arguments against that distinction: Halle 1959; Chomsky 1964; Kaye 1989; Harris 1999) and thus manages to unite the two, as argued in great detail in Pöchtrager (2006b). 
that certain consonants come with unused room which can be claimed by a preceding vowel. This is a crucial result: The NAP (cf. section 1), the requirement for a connection between what happens and where it happens, lies at the core of the theory. The reinterpretation of the fortis/ lenis distinction as structural (by reference to positions) and not as melodic (by reference to an element) can only be appreciated if non-arbitrariness is considered a central goal in linguistic theory.

The same kind of reasoning is also relevant for the representation of stops, coronality and vowel height and thus for us. We will look at stops here first and discuss coronality and vowel height in sections 3.3 and 6 , respectively.

\subsection{Stops, fricatives and affricates}

Like $\mathbf{H}$, the element responsible for voicelessness, the element $\mathbf{2}$, characterising stops, also underwent a reinterpretation in GP 2.0. This goes back to Jensen (1994), who argued that given the lopsided distribution of $\mathbf{P}$ (its failure to occur in vowels) it should be reinterpreted as structure. $^{7}$ His suggestion was based on observations like the one that in Pulaar, continuants become non-continuants ( $w \rightarrow b, f \rightarrow p$ ) when forced to govern another position, for example in a geminate. This is illustrated in (9).

(9)

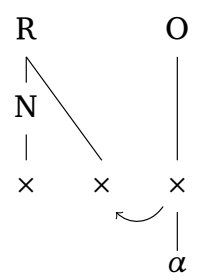

Jensen's interpretation was that stopness is an automatic consequence of the governing relationship established between the two points. Instead of positing an element $\mathbf{P}$ that would have to appear out of nowhere whenever government occurs, Jensen argued that it is the government relationship itself that encodes stopness. Conversely, a non-nuclear position without any governing duty could only be a fricative or glide (earlier characterised by the absence of 2). ${ }^{8}$ While interesting in that it remedied a distributional gap of a melodic prime, Jensen's proposal was not compatible with the model of constituent structure at the time: Not all governors are stops ( $f$ in pilfer), and not all stops are governors ( $p$ in chapter).

Pöchtrager (2006b), dealing mainly with (the elimination of) H, tried to incorporate Jensen's proposal, leading to a theory where both $\mathbf{H}$ and $\mathbf{P}$ were reinterpreted as structure. Consonants in that theory are projections of onset heads. ${ }^{9}$ We will focus on stops and fricatives here; the head-complement order is slightly modified vis-à-vis Pöchtrager (2006b).

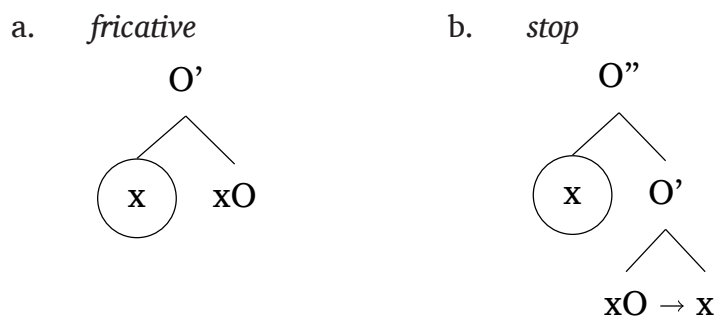

In (10), $\mathrm{xO}$ represents the onset head, which can combine with a complement and specifier. This full structure is realised in a stop (10b) which has both a complement (to its right) and a specifier (to its left). Fricatives (10a), however, only have a specifier (to the left). ${ }^{10}$

7 To my knowledge, Backley (2011) is the only proposal assuming that $\mathbf{2}$ could also occur in vowels.

8 This subsumes rhotics. Laterals and nasals contained $\mathbf{P}$ in Jensen's system.

9 The choice of name ("onset") is not entirely fortunate, since syllabic affiliation (traditional onset vs. coda) is encoded by the position in the phonological representation. "Consonant" would be no less unfortunate, given the debated status of glides.

10 A structure without a complement and only a specifier as in (10a) is somewhat surprising (and possibly unfortunate) when compared to syntax, but unavoidable at this point, it seems: The specifiers in both (10a-b) fulfil the same function, i.e. they provide a position to express the fortis/lenis contrast and (potential) lengthening. For details on why specifiers have that role (and not complements) cf. Pöchtrager (2006b). At the current level of understanding this must be taken as an axiom, but one that at least gives us the correct results as we will see throughout the text. 
The specifier (circled) is the position responsible for the fortis/lenis distinction: If claimed by $\mathrm{xO}$ itself we have a fortis consonant (bit), if left unclaimed by $\mathrm{xO}$ we are dealing with a lenis consonant (bid). The unclaimed position can then be claimed by a preceding vowel (if there is one), leading to lengthening of that vowel as discussed in section 3.1. The arrow between $\mathrm{xO}$ and its sister in (10b) represents control, a relationship that expresses the spirit of Jensen (1994): That onset heads have to "do something" to their neighbours in order to be stops. In contrast to Jensen, this relationship is contained within one constituent, instead of taking place across constituents. This avoided the problematic identification of stopness with syllabic affiliation pointed out above. In addition to that, control was also assumed to keep the controlled position silent. Beyond that, control had little function. ${ }^{11}$

It is exactly this (badly understood) notion of control that I want to develop in this paper. Contrast the definition of control given in Pöchtrager (2006b: 77, emphasis added) in (11a) with the proposal of a slightly modified one I will be using in this article in (11b).

\section{Control}

a. An unannotated $\mathrm{x}$ in a non-maximal onset projection must be controlled by its $\mathrm{xO}$.

b. An unannotated (i.e. empty) $\mathrm{x}$ in a non-maximal onset projection can be controlled by its $\mathrm{xO}$.

An " $\mathrm{x}$ in a non-maximal onset projection" refers to the complement, i.e. control can only hold between onset head and complement, but not between onset head and specifier. The difference between "must" and "can" is crucial, as it makes control only possible, but not necessary. This creates the system in (12) where three structures can be differentiated instead of just two as in (10). In addition to fricatives (12a) and stops (12c) we now also have (12b) as an intermediate structure, and that will be the affricates. Note that a conceivable fourth possibility, i.e. a structure as in (12a) but with control is excluded since control can only target the complement as stipulated in (11).
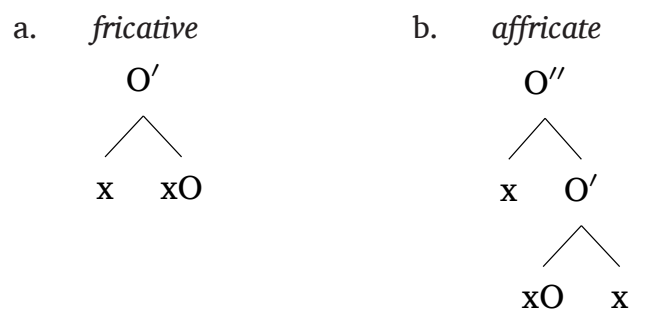

In that system, affricates take an intermediate position between fricatives and stops and thus allow for the formal characterisation of natural classes. Affricates are like fricatives in that neither one involves control (12a-b). Affricates are also like stops in that each involves two layers of projection of $\mathrm{xO}(12 \mathrm{~b}-\mathrm{c})$, i.e. they are comparable in size. Given those similarities, it becomes easier to understand why both groupings seem to be relevant for certain phonological phenomena, cf. the discussion in section 1. Furthermore, Kehrein (2002: Chapter 2) argues that affricates never form a natural class on their own. This requirement is met: Defining such a class would require a conjunction such that there is no control and that there must be two layers of structure. It is hard to see how such a random conjunction could be justified.

The representations in (12) also allow us to give a consistent semantic interpretation of control: It serves to keep the (empty) complement silent. Its absence on the other hand leads to an audible interpretation of the complement, i.e. the fricative portion of an affricate. Since fricatives do not contain a control relationship by definition, no part of them will be kept silent, i.e. there will be friction throughout. Now, empty positions have been a part of GP since its inception (Kaye 1990a; b; 1992a; Kaye, Lowenstamm \& Vergnaud 1990; Charette 1991), and have been invoked to explain vowel-zero alternations, the special role of final consonants and $s \mathrm{C}$-clusters as well as other phonotactic peculiarities. Depending on the particular location and the environment of an empty position within a phonological domain, the Empty Category Principle (ECP) would regulate whether an empty position was to be realised or kept silent. 
For example, languages can differ in whether they allow their words to be consonant-final or not: English does, Māori (Harlow 2007) does not. According to GP, all words end in a nucleus, though that nucleus might happen to be empty. A parameter can then be set which allows this nucleus to remain uninterpreted, as is the case in English. Given the interpretation of control assumed here, where an onset head keeps its complement silent, control might turn out to be subsumable under the ECP as well. This would require further argumentation, however, which I cannot undertake here as it would take us too far afield. We will come back to this issue in section 4.4, though.

Finally, it is typical for affricates to share the same place of articulation throughout (Clements 1999; Kehrein 2002). This is unsurprising, given the representations in (12): Affricates can be seen as simple stops with a special kind of release. Their place is determined once for the entire structure. Lastly, note that lenition trajectories are easily expressible as well: A change [p $\rightarrow$ pf] (stop to affricate) would simply involve the loss of control, while [p $\rightarrow$ f] (stop to fricative) involves the loss of a layer of structure (with an accompanying loss of the control relationship). ${ }^{12}$

\subsection{Coronality}

The final ingredient in our discussion will be the element A of GP 1.x which I take to correspond to [-high] in vowels as well as represent coronality in consonants (Broadbent 1991; Cyran 1997; Goh 1997). ${ }^{13}$ However, A consistently shows behaviour that is different from that of the other elements; something that has been noted before in GP as well as related models such as Particle Phonology and Dependency Phonology (Schane 1984; Anderson \& Ewen 1987; Cobb 1995; 1997; Broadbent 1999; Kaye 2000; Pöchtrager 2006b; 2012). More precisely, A interacts with (constituent) structure in that it provides more room than otherwise allowed. To illustrate, take the upper size limit of English monosyllabic words as in (13).

$$
\begin{array}{lll}
\text { a. } & \text { Either: } & \overline{\mathrm{V}} / \mathrm{VV}+\mathrm{C} \text { (meet, boot, boat) } \\
\text { b. } & \text { Or: } & \breve{\mathrm{V}}+\mathrm{CC}(\text { mint, lift, pact }) .
\end{array}
$$

Shorter words are possible (fee, pin), but the maximum is reached with a long vowel (or diphthong) plus a single consonant (13a), or a short vowel and a cluster of two consonants (13b). This limit can be exceeded to yield VCC/VVCC, provided that both consonants are coronal (Fudge 1969; Halle \& Vergnaud 1980; Selkirk 1982), i.e. contain A:

$$
\begin{aligned}
& \text { fiend but not *fiemp nor *fienk, } \\
& \text { count but not *coump nor *counk. }
\end{aligned}
$$

In other words, coronality makes bigger structures possible that we would otherwise not expect. The same holds for $s$ C-clusters (Harris 1994; Goad 2011): east, boost, haste, boast (both consonants coronal) vis-à-vis *easp, *boosk, *haspe, *boask (only first consonant coronal). ${ }^{14}$ This behaviour of A to provide extra room can not only be seen in English but is recurrent across languages (Pöchtrager 2012). German allows final CCC in monomorphemic forms, provided that the final consonant is coronal (Markt 'market', Mumps 'mumps'), and even final CCCC with the last two consonants coronal (Herbst 'autumn'). Finnish has aalto 'wave' and sääntö'rule', but no *aalpo, *aalko, *säämpö or *säänkö (monomorphemically). Such consistent interaction with structure is atypical for an element. In order to make sense of those patterns, then, GP 2.0

12 Both changes have happened in the history of (some) German (varieties) (Žirmunskij 1962).

13 Within GP other proposals have been made for coronals, cf. Backley (2011) for arguments that I represents coronality, possibly alongside A. For arguments against those arguments cf. Pöchtrager (2013).

14 Three comments are in order: Firstly, onomatopoeia defy that generalisation: oink, boink. Secondly, the data in (14) as well as those with $s \mathrm{C}$-clusters are amenable to an alternative interpretation, where the crucial factor is the final consonant being coronal, while the coronality of the preceding consonant is irrelevant (and in the case of nasals simply the result of a homorganicity requirement, anyway.) This would then also explain traipse, coax with diphthongs and clusters where only the second member is coronal (more specifically, $s$ ). Thirdly, words with three final consonants, VCCC, such as mulct, jinx also suggest that it is indeed the final consonant that matters. Standing in the way of a final decision is Southern British English, which allows for yet a further pattern: Nuclei containing A by itself can appear before $s \mathrm{C}$-clusters as long as either one of the final consonants is coronal (contains A): clasp, task, draft, but no *cleesp, *toosk, *dreeft. Here the vowel seems to make up for the insufficiency of the cluster. Still, what unites all these cases is that $\mathbf{A}$ in (certain) consonants (or vowels) provides extra room. 
assumes that something interacting with structure should be structural itself. ${ }^{15}$ The concrete implementation of that idea could be debated, but one proposal (Pöchtrager 2006b; 2010b; 2012; 2018; Kaye \& Pöchtrager 2009; 2013) is that expressions which were thought to contain A are structurally bigger than those without. Such bigger structures would contain empty positions that can be claimed by adjacent vowels and consonants and give rise to sequences that are bigger than normally allowed.

In this text I will choose an implementation that differs somewhat from earlier proposals (Pöchtrager 2006b; 2010b; Kaye \& Pöchtrager 2013). I will assume that onsets can contain the projection of another onset head that allows us to express the extra space that comes with coronality. In order to keep them separate I will use xo for the higher onset head and $\mathrm{xO}$ for the lower onset head. ${ }^{16}$ Both xo and xO are heads and, as such, can control their complement, provided that the complement is a single position $\mathrm{x}$, as per (11). Further properties of xo vis-àvis $\mathrm{xO}$ will be discussed throughout the text.

The relevant structures are given in (15). (15a-b) repeat structures we have seen before, only that $\mathrm{xO}$ is replaced by xo. Since they do not contain any melody they are interpreted as velars. $(15 \mathrm{c}-\mathrm{d})$ give the alveolar stops $[\mathrm{d} / \mathrm{t}]$ and the fricatives $[\mathrm{z} / \mathrm{s}]$. As before, the (highest) specifier in all four structures (circled) is responsible for the fortis/lenis contrast.
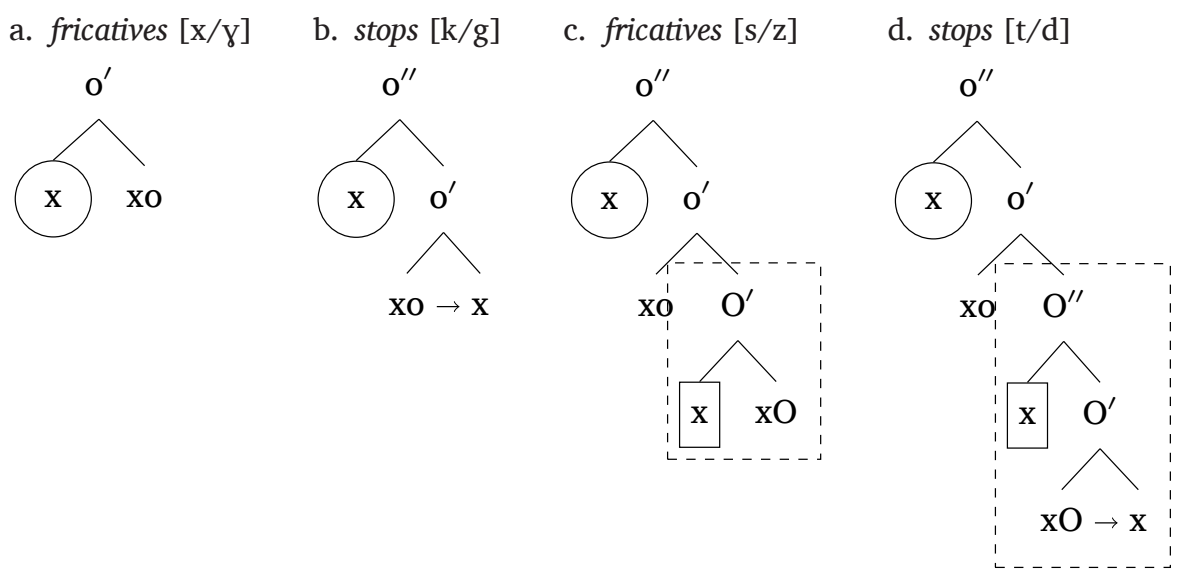

$(15 c-d)$ require further discussion. We have the projections of two heads on top of each other, with the projection of the lower one $(\mathrm{xO})$ embedded into the upper one as the sister of the upper head (xo). (As a visual aid, the lower projection is enclosed in a square with dashed lines.) Note that this embedding of a projection of $\mathrm{xO}$ makes control by the upper head xo impossible: Control can only target the sister if that sister is a single, empty position; but here we have an entire tree structure embedded as the sister of the higher head xo. Any control relationship to encode stopness will have to take place at a lower level; it is pushed down, so to speak, and has to hold between $\mathrm{xO}$ and its sister, if at all.

Focusing on the projections of the lower head in (15c-d, dashed lines) we see that they parallel the structures in (15a-b). In (15c-d) the fricative/stop distinction is expressed in the same way as in (15a-b), only at a lower level. This parallelism will also hold true for affricates, as we shall see in section 4 . In other words, the natural classes of fricatives and of stops, respectively, can still be expressed: (15a, c) are united by the lowest head projecting once, regardless of the identity of the head (xo, xO). Likewise, (15b, d) form a class by virtue of the lowest head projecting twice. At the same time, coronals can be uniquely identified by having a lower head $\mathrm{xO}$, which cuts across the distinction of continuancy. This lower head (together with the absence of any elements) makes sure that $(15 c-d)$ come out as coronal. ${ }^{17}$

The lower head (in 15c-d) also has an empty non-head position to its left (boxed) which, I submit, is the very position responsible for why coronals allow bigger structures, as we saw at the beginning of this section: This position can be "borrowed" from the coronal.

15 This is reminiscent of the fate of the feature [ \pm long] (Fox 2000).

16 In section 6 we will see that the same bipartition applies to nuclei.

17 The old debate whether velars or coronals are more unmarked, cf. many of the contributions in Paradis \& Prunet (1991), becomes less puzzling given that in this approach both velars and coronals lack elements. 
That is, in a word like fiend in (14) we have a long vowel and a coronal cluster, going beyond what is usually possible. In order to fit in a long vowel the extra non-head position will have to be used. ${ }^{18}$ Finally, the position that is responsible for the fortis/lenis contrast (circled) is in its usual place, i.e. as part of the projection of the upper head. As we shall see, this particular replacement of (old) A will allow us to single out coronals when we get to affrication.

\subsection{Interim summary}

Let us sum up the main assumptions that will be relevant to our account of affrication.
a. Coronality is expressed as extra structure.
b. As a result, the control relationship to yield a stop is pushed further down.
c. Affricates lack a control relationship which stops require.

These three points will not be sufficient for a complete account of affrication and palatalisation, but they will allow us to deal with the undergoers of those processes, which we will start with. More precisely, we will start with the cases where affrication and palatalisation cooccur in section 4. In section 5 we will move on to those without palatalisation. Finally, we will concern ourselves with the triggers in section 6 , thereby completing the analysis.

\section{Accounting for affrication and palatalisation}

\subsection{Japanese vs. Brazilian Portuguese}

Consider again what happens in Japanese before a high front vowel/glide. (17) repeats (5a).

\begin{tabular}{|l|lllll|}
\hline Japanese & $\mathrm{t}$ & + & $\mathrm{i}$ & $\rightarrow$ & $\mathrm{t} \int \mathrm{i}$ \\
& $\mathrm{s}$ & + & $\mathrm{i}$ & $\rightarrow$ & $\int \mathrm{i}$ \\
\hline
\end{tabular}

The vowel [i] acts as a trigger. It contains the element I which spreads into the consonant, trying to get close to the (lower) head. (The reasons for this will be addressed in detail in the following subsections.) I will assume that elements coming from outside cannot spread straight into a head position but only a non-head position. This will be the complement in a stop and the specifier in a fricative. This is represented in (18).

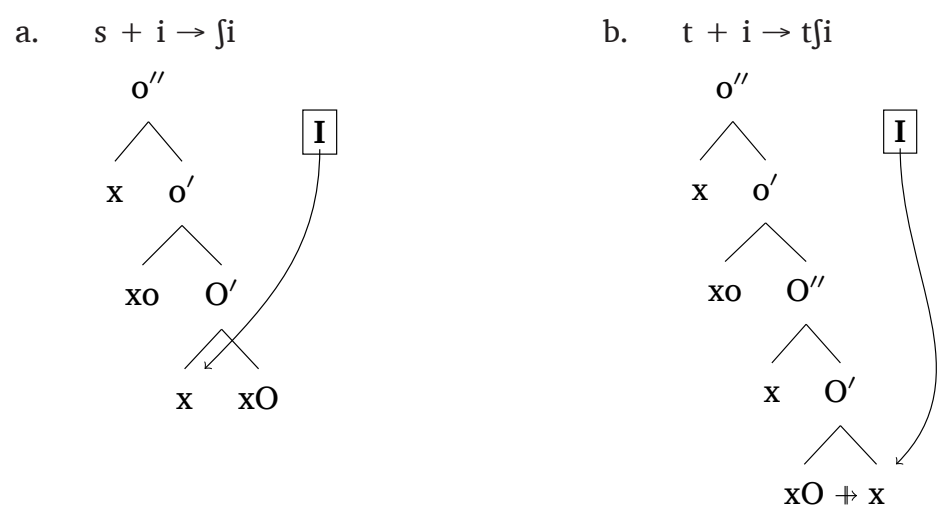

In fricatives, the simpler case, I spreads from a following vowel or glide into the specifier of $\mathrm{xO}$ (18a). The only effect that this has is the palatalisation of the fricative. This differs from stops (18b) where we see affrication in addition to palatalisation. Crucially, those two are linked: As before, I spreads into a non-head position close to the head $\mathrm{xO}$, i.e. the complement. Those two positions already entertain a control relationship. Control can only target an empty position, and with I moving into the sister of $\mathrm{xO}$, that position is no longer empty. As a result, control has to be severed, deriving the structure of an affricate. In other words, affrication here is the consequence of a lost control relationship, which is in turn directly linked to the spreading of $\mathbf{I}$. That fricatives should only have place affected, but stops place and manner, falls out from the assumptions we have made so far. 


\begin{tabular}{|l|lllll|}
\hline Br. Port. & $\mathrm{t}$ & + & $\mathrm{i}$ & $\rightarrow$ & $\mathrm{t} \int \mathrm{i}$ \\
& $\mathrm{s}$ & + & $\mathrm{i}$ & $=$ & $\mathrm{si}$ \\
\hline
\end{tabular}

Stops palatalise and affricate in the same way as in Japanese, so we can assume that the same mechanism is at work. ${ }^{19}$ Fricatives, on the other hand, behave differently from Japanese in that they are unaffected by a following $i .^{20}$ In Japanese, I goes into the sister of the head $\mathrm{xO}$, no matter if that is a complement or a specifier. In Brazilian Portuguese, it goes into the complement, but not the specifier:
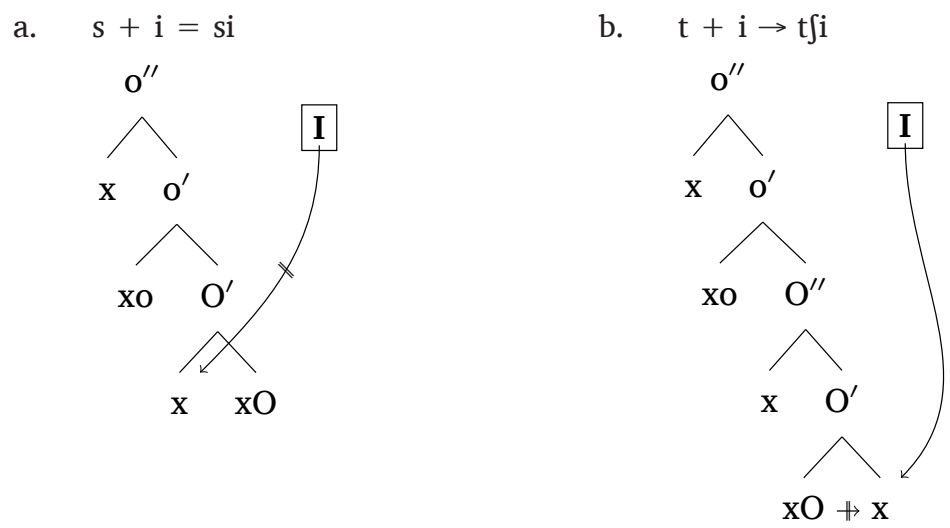

While this accounts for the facts, it leaves at least three questions unanswered:

a. Why are only coronals targeted? Formally: Why is the projection of the lower head $\mathrm{xO}$ the target of I-spreading?

b. Why does Brazilian Portuguese restrict spreading to coronal stops as targets? Formally: Why does I not spread into the specifier in (20a)?

c. Even if I is restricted to non-head positions, why does I not go into the specifier of $\mathrm{xO}$ in Japanese $t(18 \mathrm{~b})$, which would leave stopness untouched?

The answers to all three questions are tightly connected and will be addressed in the following subsections. Some crucial clues will come from English, which shall turn to now.

\subsection{Why coronals? Clues from English}

In section 3.3 I argued that coronals contain more structure, which comes about by having the projection of a lower head (xO) embedded in the projection of a higher head (xo). Coronals are thus fairly big objects. In this section we will look at a process that targets coronal stops, viz. English lenition in the shape of tapping (of $[d / t]$ ) and glottalisation (of $[t]$ ). Like so many other aspects of the theory, lenition will have to do with structure, in particular with various simplifications in weak positions. English shows us that the head $\mathrm{xO}$ and its relationships to other positions play a central role.

Within earlier versions of GP, tapping and glottalisation (city ['sıri] ['sı?i]) have been analysed as element depletion in prosodically weak positions (Harris \& Kaye 1990; Harris 1994), i.e. foot-internally or finally. Such weak positions are claimed to license fewer elements, as a result of which a coronal stop breaks down into a tap or a glottal stop whose elements form subsets of those of a full-blown stop. This was in parallel to the account chosen for vowel reduction (Harris 1997), where again lenition could be modelled as element loss in many, though not all cases. Note that while stops were relatively complex (i.e. rich in elements) in those approaches, there was still no way to single out coronal stops other than by stipulation, since coronal stops had the same number of elements as labial stops.

19 For quality differences in the affricates see section 4.5 .

20 Recall that not all varieties of Brazilian Portuguese palatalise/affricate stops; and note furthermore that some varieties do palatalise $s$, but in different contexts (and thus not immediately relevant to us), e.g. in the coda: haste 'stick' ['asti] [ast $\left.\int \mathrm{i}\right] \sim$ [aft $\left.\int \mathrm{i}\right]$, cf. Cristófaro-Silva (2003) for details. 
In the current approach, much of what was melody (i.e. elements) has been replaced by structure. As a result, many cases of lenition, both for consonants (Pöchtrager 2016) and vowels (Pöchtrager 2018), have been reinterpreted as structural as well. This can mean one of two things, as given in (22).
a. Loss of particular positions in a tree structure (which might entail the loss of a relationship a position is involved in).
b. Loss of a relationship between positions, while the positions themselves remain.

The affrication patterns in previous sections were examples of (22b). Here, spreading of an element I into the complement position led to the removal of a control relationship, while the positions involved remain in place. Likewise, lenition of a fortis consonant to a lenis consonant would mean an onset head xo gives up its claim on the specifier (cf. section 3.1). As for (22a), going from a stop to a fricative involves the removal of a complement position (along with the control relationship it is targeted by) and thus, since the trees of GP 2.0 are uniformly binary branching, also the removal of the intermediate projection. ${ }^{21}$

In the same fashion, going from a coronal stop to a tap involves the removal of layers of structure. (Structures anon.) Reference to structural pruning (22a) seems promising in the analysis of lenition, since purely quantitative (length) contrasts are also often lost in prosodically weak positions. Taking tapping, glottalisation, vowel reduction etc. as structural allows for a formal unification with quantitative changes that have been understood as structural at least since the demise of the feature $[ \pm$ long]. The question is then: What makes coronal stops special such that they are targeted by various kinds of lenition in many varieties of English (Harris 1990: Section 5 and references therein)? This is nearly identical to the question why Brazilian Portuguese singles out stops in (21bii). English better is affected by tapping/glottalisation, pepper and bicker are not, and neither is the affricate in butcher (whose I in complement position is not the result of spreading but lexically present). The same holds for tapping and medal vs. its absence in cable, beggar, ledger. (23) gives the representations of the relevant consonants, leaving fortis/lenis (expressed in the circled specifier) unspecified.
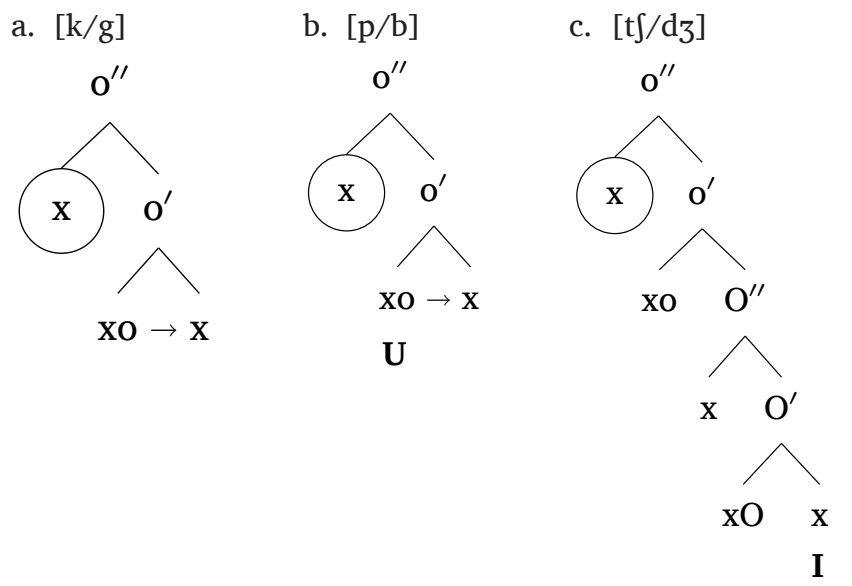
Now, different varieties react differently to that problem. Interestingly, what seems like the simplest option, viz. removal of control (and thus affrication to [ts/dz]) does not occur. Instead, English typically opts for more dramatic solutions to the problem, tapping and glottaling, both of which involve the removal of major parts of the structures:

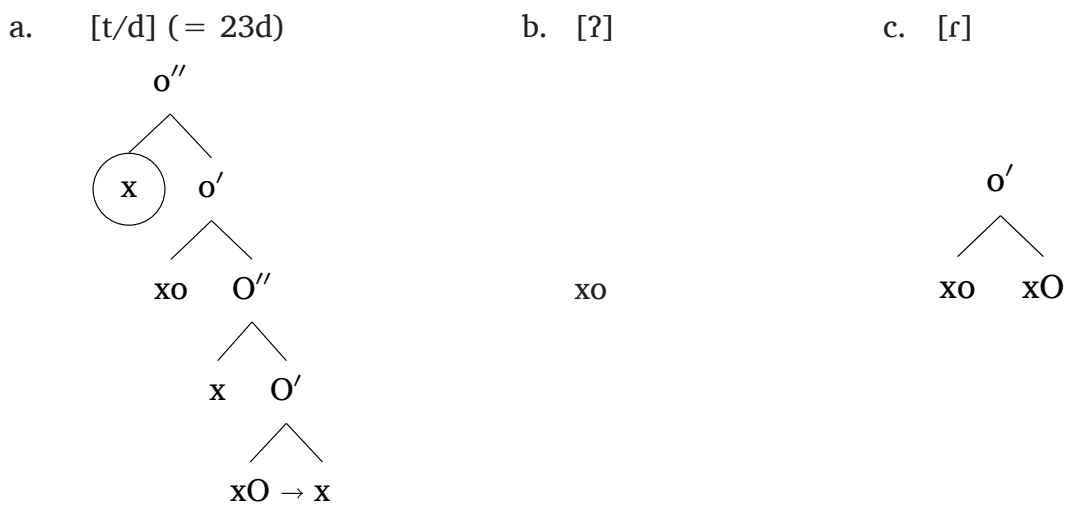

Both options make sure that $\mathrm{xO}$ does not control a complement, but also lay waste to much of the remaining structure. ${ }^{22}$ In (24b) $\mathrm{xO}$ and its entire projection up to $\mathrm{O}^{\prime \prime}$ is removed, leaving us with an object that is accordingly no longer coronal. In (24c) all the non-heads of $\mathrm{xO}$ are removed and only the head of the coronal component, $\mathrm{xO}$, survives. All of this is in reaction to the control relationship entertained by $\mathrm{xO}(24 \mathrm{a})$. The removal of (parts of) the projection of $\mathrm{xO}$ is, as we shall see several times again, a typical pattern of lenition. In fact, even more generally, trees seem to be operated on from the bottom upwards, and removal of relationships/positions is just one kind of operation. That English also removes part of the projection of the higher head xo might have to do with tapping/glottaling being prosodically conditioned. ${ }^{23}$ So let us come back to affrication where this is not the case.

\subsection{Affrication and the specifier/complement asymmetry}

For coronal stops in Japanese and Brazilian Portuguese I have proposed that I spreads into a controlled position and breaks up the control relationship, thus leading to both affrication and palatalisation. No structure is lost, but a relationship between two positions is, cf. (22b). Crucially, the relationship that is lost holds between the lower head $\mathrm{xO}$ and its complement, the same relationship that is singled out as problematic in English. I will therefore assume that coronals are targeted by palatalisation (and affrication) because of the lower head $\mathrm{xO}$ they involve. In fact, the idea that trees are operated on from the bottom upwards, as suggested in the previous section, also allows us to make sense of the asymmetry between Japanese and Brazilian Portuguese noted in section 4.1: Before high front vocoids Brazilian Portuguese only palatalises/affricates $t$, while in Japanese both $t$ and $s$ are affected. This subset relationship can be derived from the trees: a. $[\mathrm{s}]$

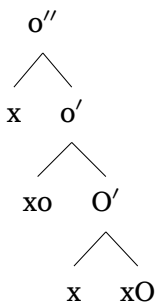

b. $\quad[\mathrm{t}]$

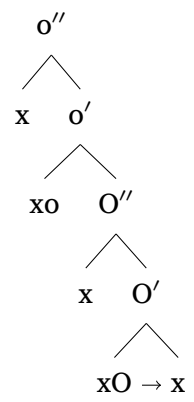


Firstly, I going down as far as possible when spreading to these consonants follows from the assumption that operations take place starting from the bottom; that the bottom part forms a kind of entry point. The specifier of $\mathrm{O}^{\prime \prime}$ in (25b) is thus not a candidate for I to go to. Secondly, under an adequate formulation of "further down" we can see why Brazilian Portuguese would affect (25b) to the exclusion of (25a): The complement is further down from the maximal projection than a specifier, and thus (25b) with its complement is affected preferentially, but (25a), where there is only a specifier, is not. By the same token, lenition in English targets coronal stops, not any coronal obstruent. ${ }^{24}$

\subsection{Korean}

Before moving on to cases where affrication and palatalisation part ways, let us consider one last case where they are linked. Our account so far also helps us to make sense of Korean (Heo 1994; Chang 1996; Kim 1996; Lee 1999; Sohn 1999; Song 2005; Shin, Kiaer \& Cha 2013), even though what happens is not the creation of an affricate but the undoing of one. The full range of Korean obstruents can only be seen before a realised vowel. Before a silenced empty nucleus (word-internally \& finally) all consonants must be non-continuant (Heo 1994; Kim 1996). This leads to whole-sale neutralisations, an extreme example of which is found in (26), taken from Chang (1996: 16).
a. [nad-il] 'grain OBJ.'
b. [nat ${ }^{\mathrm{h}}$-il] 'piece OBJ.'
c. [nas-il] 'sickle oBJ.'
d. [nadz-il] 'day oBJ.'
e. $\left[\right.$ nat $\int^{h}$-il] 'face oBJ.'

\section{[nat? $]$ BASE}

The changes affect continuancy and phonation, with one exception: Palatoalveolar affricates (26d-e) end up as alveolar stops. ${ }^{25}$ Now, why should place of articulation change in exactly this one particular case? In light of our account so far, a simple interpretation presents itself: Turning an affricate into a stop must mean the addition of a control relationship between an onset head and its complement. Control can only target empty positions by definition, but in palatoalveolar affricates we find an $\mathbf{I}$ in the complement position. It is easy to see how the addition of control would force out the element $\mathbf{I}$ and thus change a palatoalveolar affricate to an alveolar stop, thus explaining the change in place and why it happens in exactly this one instance. However, there are still four questions to be answered: i. Why is control added? ii. How is this connected to the specific environment where this neutralisation happens? iii. How/ why can we tamper with I? iv. How do we express the change from fricative to stop (26c)? As we shall see anon, the answers to each question are linked.

Earlier GP analyses of Korean (Heo 1994; Kim 1996) assumed that neutralisation takes place because the following silenced empty nucleus cannot license certain elements. Weirdly enough, though, at the same time that nucleus seems to require other elements, viz. the (old) stop element $\mathbf{2}$, to make sure that even a fricative ends up as a stop, suggesting that weak licensing power is not the source of neutralisation. Let us assume instead that the following empty nucleus, in order to be silenced, is controlled by a preceding onset head, be it xO or xo. (The former in the case of coronals, the latter elsewhere.) In section 3.2 we have already seen that control has the function of keeping a position silent and seems to form part of the ECP. In order to be controlled, then, an empty nucleus (represented by the nuclear head xn) needs to be the sister to an onset head. Since a head projects maximally twice (as in stops and affricates), controlling a following nuclear head means that the original complement has to be jettisoned, and with

24 In general, I spreads quite aggressively in Japanese and also to the alveolar nasal, though Labrune (2012: 78) points out that this is "not very marked" (and therefore not discussed so far), but cf. also Chen (1996: 29-32). Nasals are stops, so this is not surprising, though I have no answer at this point why this does not lead to affrication (or what that would even mean for a nasal).

25 In the phonological literature, Korean palatoalveolar affricates are also referred to as (palatal) stops (Kim 1996; Sohn 1999; Song 2005), and often also transcribed as such ([c, c', ch]), even by authors who then refer to them as affricates (Chang 1996; Heo 1994). Elsewhere they are treated as affricates (Lee 1999; Shin, Kiaer \& Cha 2013), as the fricative release is audible and visible in spectrograms. Kim $(1999 ; 2001)$ also takes issue with the place of Korean affricates (alveolar, not palatoalveolar), but not their status as affricates. This does not affect (or at worst minimally affects) the argument from neutralisation considered here. 
it we lose the element $\mathbf{I}$ it hosts. The nuclear head takes its stead (and becomes effectively integrated into the onset), and the formerly palatoalveolar consonant ends up as alveolar. This is shown in (27a). ${ }^{26}$

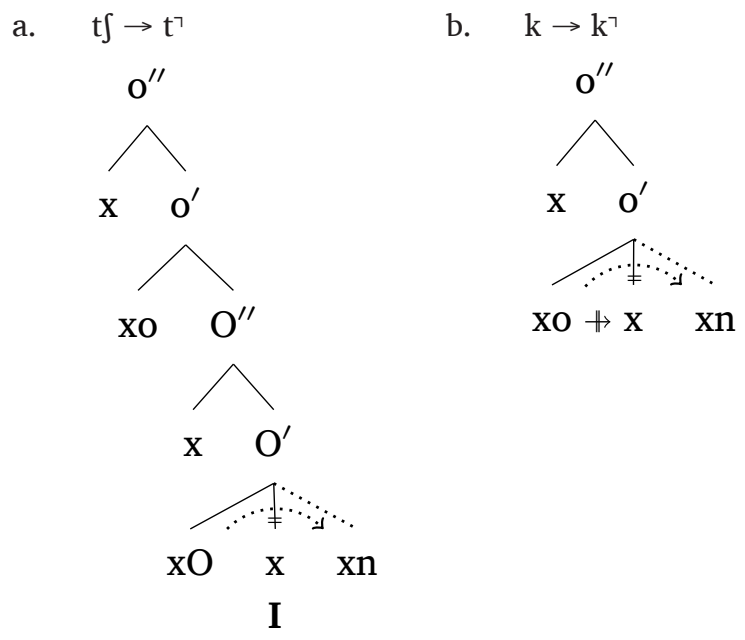

This operation thus leads to both a change in place and manner. (I assume that the lack of release is concomitant with the nucleus being integrated into the onset.) The same will happen to any stop, e.g. the velar stop in (27b), but since there is control to begin with, little will happen except that the original empty non-head position is replaced by an empty nuclear head xn in need of being silenced, and thus the release is lost. Finally, the fricative $s$ has an $\mathrm{xO}$ that only projects once, i.e. there is room for the following xn to be controlled and integrated without giving up any positions; this integration is shown by $\mathrm{O}^{\prime}$ in a dotted box in (27b). (Note that no positions are added; the bar level of old $\mathrm{O}^{\prime}$ is simply adjusted accordingly when $\mathrm{xO}$ and $\mathrm{xn}$ form a projection.) We predict the result to be an unreleased stop, which is of course correct. $^{27}$

Summing up, focusing on how the empty nucleus following the neutralisation site can be silenced has allowed us to explain why affricates and fricatives end up as stops as well as why palatoalveolars turn into palatals. The proposal for the internal structure of affricates that we have developed on the basis of affrication and palatalisation patterns in other languages provides exactly the tools needed to give a non-arbitrary account of Korean neutralisation. ${ }^{28}$ Note furthermore that yet again an operation affecting a consonant starts at the bottom of the represention, with $\mathrm{xn}$ being integrated into the preceding onset.

\subsection{Japanese affricates again}

As noted in section 2, Japanese affricates are alveolo-palatal [tc], [dz] rather than palatoalveolar $[\mathrm{t}] \mathrm{,}\left[\mathrm{d}_{3}\right]$ as in Brazilian Portuguese, a difference which we have ignored so far. To the extent that this difference can be phonologically relevant as in Polish (Rubach 1994; Gussmann 2007), our theory should provide different representations. For Japanese and Brazilian Portuguese we assumed that I spreads into the complement position of the preceding consonant. This guarantees not only palatalisation, but also affrication. The phonetic difference between [tc], [dz] and [t]], [d3] must lie elsewhere. I will assume that in Japanese, I spreads further from the sister of the head into the head, while it fails to do so in Brazilian Portuguese. That is, I in Japanese spreads into the sister of the head and from there into the head (so both positions are interpreted as containing I), while in Brazilian Portuguese its journey ends in the complement

26 As for a node dominating two heads, $\mathrm{xO} / \mathrm{xo}$ and $\mathrm{xn}$, the reader is referred back to fn. 22 .

27 That an empty nucleus should be integrated into a preceding onset might seem surprising. However, as Heo (1994: Chapter 4) makes clear, the silencing of (at least internal) empty nuclei depends not only on the right-hand context as is often the case with the ECP (Charette 1991), but also on the nature of the preceding onset, which is exactly what this analysis leads us to expect.

28 Clearly, this is not a complete analysis of Korean neutralisation, since laryngeal changes, also seen in (26), have not been addressed. For those, the highest specifier will presumably play a crucial role, the analysis of which will have to be left for a later date. 
position. This expresses the idea that alveolo-palatals are further front, because I actually makes it into the head, instead of being associated with a non-head only. ${ }^{29}$

\subsection{Interim summary}

Our account so far can handle affrication, palatalisation and the relationship between the two. Up to this point, we have mostly been concerned with the internal structure of the consonants undergoing the change, but not so much with the internal structure of the triggers. In order to get there, we will take what seems like a detour, i.e. a case where affrication occurs independently of palatalisation. This, however, will be a necessary step in understanding the nature of the triggers.

\section{Action without touching}

\subsection{Affrication without palatalisation}

Let us now move on to Québec French. (28) repeats the relevant data from (5e).

\begin{tabular}{|l|lllll|}
\hline Qu.Fr. & $\mathrm{t}$ & + & $\mathrm{i}$ & $\rightarrow$ & $\mathrm{tsi}$ \\
& $\mathrm{s}$ & + & $\mathrm{i}$ & $=$ & $\mathrm{si}$ \\
\hline
\end{tabular}

Several comments are in order here. Firstly, affrication happens before [i, I, y, y] alike. The vowels [i, I] contain I, [y, Y] both $\mathbf{I}$ and $\mathbf{U} .{ }^{30}$ No change is triggered before [u, u], i.e. by vowels that contain only the element U. Secondly, like in Brazilian Portuguese, fricatives are not affected by palatalisation. Thirdly, in contrast to Brazilian Portuguese we see affrication here without palatalisation: $[\mathrm{ts} / \mathrm{dz}]$ but not $*\left[\mathrm{t} / / \mathrm{d}_{3}\right]$. Since there is no palatalisation we have to conclude that I does not spread. But if that is correct, and if affrication means that a control relation is lost, what is the reason for control being lost then? There is no other property that would qualify as a potential trigger: We cannot generalise to high vowels (since the high back vowels $[\mathrm{u}, \mathrm{v}]$ do not trigger) or unrounded vowels (since the high front rounded vowels [y, $\mathrm{Y}$ ] do trigger) etc. I is a crucial ingredient that cannot be reduced to anything else. It is as if the mere presence of $\mathbf{I}$ in the following high vowel was enough to trigger a change. ${ }^{31}$ This is somewhat surprising for a model like GP that clearly subscribes to the autosegmental idea that phonological processes should be modelled by spreading and delinking of material, and ideally only by that (as argued quite explicitly in Kaye, Lowenstamm \& Vergnaud 1985; 1990; Kaye 1989; 1995). And yet here we are dealing with a case where we can identify a trigger (I in high vowels) that effects a change we would expect if I did spread (so that Non-Arbitrariness would be satisfied), only that I does not spread. We seem to have "action without touching" here.

Good parallels to such a phenomenon are hard to find. Transconstituent government between an onset and a preceding coda, as assumed in earlier versions of GP, comes close: In English tem.per, the onset [p] was assumed to govern the coda [m], and homorganicity ( $\mathrm{U}$ being shared between governor and governee) was a visible sign of that governing relationship. In (rhotic) car.pet there was also a governing relationship between the onset [p] and the coda [r], yet in this case there is no homorganicity and no element shared between the two. Still it is reasonable to assume that government holds in both cases, since such an assumption makes correct predictions with respect to constituent structure, the distribution of vowel length before a coda and the restrictions on the types of clusters we find (all of which discussed in detail in Kaye 1990a; Harris 1994; Harris \& Gussmann 1998). Government might not be observable directly there, but had indirect consequences. So-called virtual geminates (van der Hulst 1984; 1985; Larsen 1994; Ségéral \& Scheer 2001; Scheer 2003) present a somewhat similar case,

29 Živanovič \& Pöchtrager (2010) made a similar argument about labials (U in head position) vs. labiovelars (U in specifier) in Putonghua, where the phonetic difference was accompanied by a difference in behaviour. At this point it is unclear to me what kind of behaviour would further support the particular position of $\mathbf{I}$ in [tc], [dz] visà-vis $\left[\mathrm{t} \int\right],[\mathrm{d} 3]$. A reviewer inquires whether the distinction even matters in Japanese and Brazilian Portuguese, as there is only one type in each language. But phonological theory should try to characterise what is universally possible, under which conditions, and what choices languages make. For a similar sentiment, and a somewhat different approach to Polish alveolo-palatals and palatoalveolars cf. Backley (2011: 107).

30 Pöchtrager (2020) deals with the tense/lax contrast. (In English, though, not Québec French.)

31 The restriction to high vowels is crucial since mid front vowels also contain I yet do not trigger affrication; cf. section 6 . 
though even more indirect: Those have been posited in order to explain why consonants in certain languages behave as phonologically long even though they are measurably short.

The question we then have to pose is this: Is there a relationship that has the same effect as spreading without actual transferral of melody? This is illustrated in (29) with a dashed line representing said relationship.
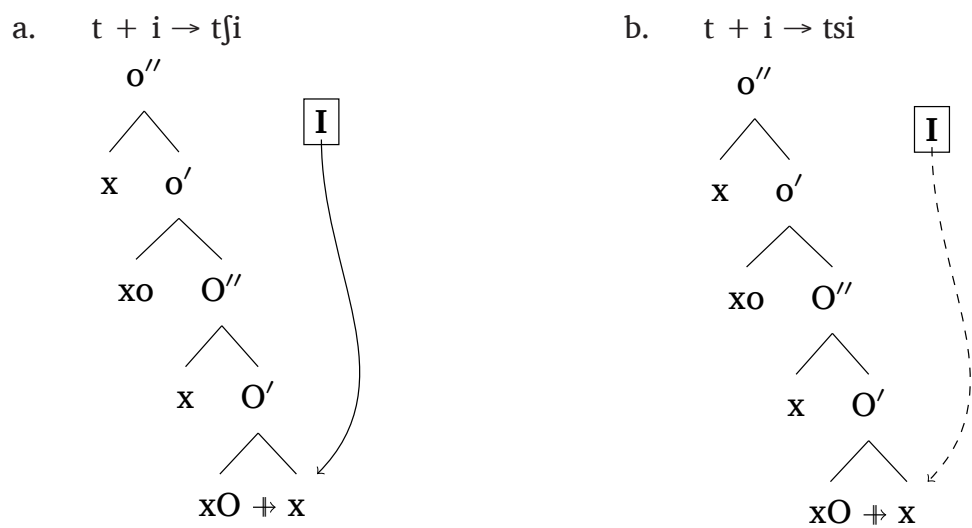

(29a) repeats the change we have seen for Japanese and Brazilian Portuguese: I spreads into an empty position, disqualifying that position as a controllee, breaking up control and leading to affrication. (29b) expresses the idea that I can have the effect of breaking up control without being interpreted itself in the complement position.

I will refer to that relationship in (29b) as preparatory spreading. "Preparatory" because "regular" spreading leads to the interpretation of a particular phonological property in the target position: I spreads from a vowel into a coronal consonant and makes it palatoalveolar, i.e. adds a palatal component to the consonant. This is not the case in (29b). It is preparatory because it clears the way, making sure that the recipient position qualifies for potential spreading in principle. In our case, this means that the target position cannot be controlled, leading to affrication in turn. In other words, in preparatory spreading there is a consequence for the target, even though the target is not interpreted as if the spreading property was associated to it.

While perhaps strange from the point of view of phonology, potential syntactic parallels are actually easier to come up with, insofar as the distinction between overt and covert movement is acknowledged. Consider covert operations such as wh-in-situ in (certain) languages (Chomsky 1995; Pesetsky 2000; Cheng 2003a; b; Bayer 2006) or quantifier raising (May 1977; 1985; Fox 2003). In both cases, syntactic movement takes place without accompanying pied-piping of the phonological material. While there is a syntactic operation necessary for interpretative purposes (i.e. its effects are real and amenable to analysis), there is no visible effect in terms of word order. This comes close to what we see in (29).

While this gives us a handle on the Québec French facts, an important question arises. It is obvious that affrication in Québec French is somehow brought about by the presence of the element I. But there is no audible indication of spreading, so why should the relationship in question even be treated as a subtype of spreading and not something altogether different? For example, instead of speaking of preparatory spreading, one could split spreading into two separate processes; let us call them "clearing" and "pasting". In such a hypothetical scenario regular spreading, i.e. the kind we have known since at least Goldsmith (1976), would involve clearing (making sure the target qualifies by removing obstacles like control) as well as pasting (associating a property with the target). ${ }^{32}$ The preparatory spreading advocated here would only involve clearing, but no pasting. Such a separation would not only lead to questions of how separate the two steps really are (could there be pasting without clearing?), it would also mean that characteristics associated with one (say, restrictions on locality, typical spreading behaviour) do not necessarily transfer to the other. In contrast, by keeping the two halves together and distinguishing instead between preparatory spreading and (regular) spreading as proposed here, we make a different prediction: That both kinds of spreading have similar properties and are closely related. This leads to the more general question of how we expect I

32 There is a certain similarity to "delinking-cum-spread" analyses involving binary features (Kiparsky 1985: 98), except that "clearing" would not involve the removal of a feature but of a control relationship. 
and other elements to behave in spreading processes, which is the subject matter of the next section.

Before that, however, let me stress that I do not assume that all affricates come about by synchronic processes of affrication, i.e. a difference has to be made between the existence of a process of affrication and the existence of affricates in a language. German has an affricate [ts], but its distribution is in no way linked to the quality of the following vowel, and it is certainly an affricate underlyingly in Modern German. Put differently, affricates (stop structures without control) are possible also without some agent that first has to break a control relationship. However, as for synchronic processes of affrication I would assume that there is a connection to the context in the shape of spreading, and if there is no audible sign of spreading besides affrication itself, then it must be of the preparatory kind.

\subsection{Asymmetries between I and U}

As the discussion in section 2 (especially the chart in (5)) showed, Japanese has affrication both before front [i] (and its counterpart, the glide [j]) and back [u]; Brazilian Portuguese and Québec French only before the high front vowel (and high front glide), but not before back vowels. Korean and English also show no affrication before high back vowels.

While five languages are not enough to base sweeping generalisations on, it is important to note that the asymmetry is also supported by the typological surveys in Bhat (1978), Kochetov (2002), and Bateman (2007). In addition, the asymmetry revolves around I vs. $\mathrm{U}$ as triggers, whose differences in behaviour have been noted time and again within GP (Charette \& Göksel 1994; 1996; Denwood 1997; Polgárdi 1998; Polgárdi \& Rebrus 1998; van der Torre 2003; Pöchtrager 2006a; 2010a; 2015; Živanovič \& Pöchtrager 2010; Mutlu 2017), also, and crucially, quite independently of affrication. Those differences show in the propensity of the two elements to spread, but also in distribution. For example, Turkish vowel harmony is characterised by I spreading freely, while $\mathbf{U}$ is subject to certain restrictions (Charette \& Göksel 1994; 1996; Polgárdi 1998; Pöchtrager 2010a). The denominal adjectival suffix -li/-lu/-lü/-lI appears in four different forms resulting from the spreading of $\mathbf{I}$ and $\mathbf{U}$, respectively: - li (spreading of I), -lu (spreading of $\mathbf{U}$ ), - -lü (spreading of I and $\mathbf{U}$ ), -lı (spreading of neither, showing the underlying form of the suffix, an empty nucleus). Thus, in söz-lü 'verbal' the suffix receives its I and U from the stem, while in hak-lı 'right ADJ.' there is neither I nor $\mathrm{U}$ to receive from the stem. This differs from the plural suffix: In söz-ler 'words' (contrast: hak-lar 'rights N.) we see I spreading, but not U. Different interpretations of why U fails to spread can be given, but the fact remains that $\mathbf{U}$ will not make its way into suffixes with a non-high vowel like -lar. ${ }^{33}$ Such an asymmetry is not atypical. In general, U-harmony implies I-harmony (Kaun 1995). ${ }^{34}$ Finnish (Pöchtrager 2006a), for example, only has I-harmony; Hungarian has I-harmony, while U-harmony as a phonological process has been called into question (Polgárdi \& Rebrus 1998) etc.

Similar remarks can be made about distribution. The typological observation that the height distinctions in back vowels do not outnumber those in front vowels (Crothers 1978: 122) follows if $\mathbf{I}$ is as least as free in its distribution as $\mathbf{U}$. With this in mind, let us again consider the general overview in (30), repeated from (5).

\begin{tabular}{|l|cccccccccccc|}
\hline Japanese & $\mathrm{a}$. & $\mathrm{t}$ & + & $\mathrm{i}$ & $\rightarrow$ & $\mathrm{t} \int \mathrm{i}$ & $\mathrm{b}$. & $\mathrm{t}$ & + & $\mathrm{u}$ & $\rightarrow$ & $\mathrm{tsu}$ \\
& & $\mathrm{s}$ & + & $\mathrm{i}$ & $\rightarrow$ & $\int \mathrm{i}$ & & $\mathrm{s}$ & + & $\mathrm{u}$ & $=$ & $\mathrm{su}$ \\
\cline { 2 - 10 } Brazilian Portuguese & $\mathrm{c}$. & $\mathrm{t}$ & + & $\mathrm{i}$ & $\rightarrow$ & $\mathrm{t} \int \mathrm{i}$ & $\mathrm{d}$. & $\mathrm{t}$ & + & $\mathrm{u}$ & $=$ & $\mathrm{tu}$ \\
& & $\mathrm{s}$ & + & $\mathrm{i}$ & $=$ & $\mathrm{si}$ & & $\mathrm{s}$ & + & $\mathrm{u}$ & $=$ & $\mathrm{su}$ \\
\cline { 2 - 9 } & $\mathrm{e}$ & $\mathrm{t}$ & + & $\mathrm{i}$ & $\rightarrow$ & $\mathrm{tsi}$ & $\mathrm{f}$ & $\mathrm{t}$ & + & $\mathrm{u}$ & $=$ & $\mathrm{tu}$ \\
& & $\mathrm{s}$ & + & $\mathrm{i}$ & $=$ & $\mathrm{si}$ & & $\mathrm{s}$ & + & $\mathrm{u}$ & $=$ & $\mathrm{su}$ \\
\hline
\end{tabular}

33 The aforementioned references for Turkish vowel harmony differ in their conclusions why $\mathbf{U}$ fails to spread, the presence of $\mathbf{A}$ being one possibility. In the present account reference to A can only be achieved by a structural reinterpretation of that restriction. This does not affect the point at hand.

34 Kaun (1995) (working in a framework without I and U, though) presents a very extensive survey, where Mongolian comes up as the only counterexample to that implication. 
If (30e) is taken as a case of spreading, albeit only preparatory, then (30f) is not surprising: Once again, $\mathbf{I}$ is less restricted than $\mathbf{U}$ in that only $\mathbf{I}$ shows preparatory spreading, and $\mathbf{U}$ not even that. A similar observation can be made for (30c) and (30d): I spreads while U does not, but this time the spreading is real and not only preparatory. Finally, an asymmetry can also be found between (30a) and (30b): I causes affrication and palatalisation, $\mathbf{U}$ only affrication but no additional change in quality. Translated into our terms, I in (30a) shows real spreading, $\mathbf{U}$ in (30b) only preparatory spreading.

Preparatory spreading also helps us to make sense of situations where different triggers lead to the same result. In (30e) and (30b) we find different vowels acting as triggers ([i] and [u], respectively), yet the change in the consonant ( $[t \rightarrow t s])$ is identical. Under the current account this is not surprising: Both (30e) and (30b) involve preparatory spreading, one time of I and one time of $\mathbf{U}$, but since the only effect is the loss of a control relationship with no further transferral of melody, the consequences for the consonant will be identical. The change $[t \rightarrow$ ts] is exactly what we would expect if an element was to spread, minus the actual (acoustic) effect of spreading.

Notice that this does not yet explain why the asymmetry exists; it only says that the asymmetry comes back in the same shape (as a readiness to spread) in several areas of grammar. The important point is that by treating all cases of affrication (not affricates, cf. the end of section 5.1) as the result of spreading, we can begin to understand why even cases of preparatory spreading are subject to the same conditions as "regular" spreading. The higher principles from which to derive the general asymmetry between I/U are still lacking. While Živanovič \& Pöchtrager (2010) and Pöchtrager (2015) proposed general principles to regulate the distribution of I and $\mathbf{U}$ when both are present, and the distribution of $\mathbf{I}$ in relation to empty positions, none of this derives the spreading asymmetry (yet). ${ }^{35}$

One important question remains: Does preparatory spreading open a Pandora's box of "anything goes"? I do not believe it does. The effect of ("real") spreading can be established by Japanese [ti $\left.\rightarrow \mathrm{t} \int \mathrm{i}\right]$ : I spreads, leading to palatalisation and affrication (loss of a control relationship because of I barging in). That case gives us a clear indication of what individual changes to the consonant to expect. Preparatory spreading fulfils that expectation at least in part by leading to affrication, but palatalisation fails to occur because spreading is only preparatory. Contrast this to a (hypothetical) situation where [tu $\left.\rightarrow \mathrm{t} \int \mathrm{u}\right]$. Such a scenario is excluded by our account: While spreading of $\mathbf{U}$ (real or preparatory) could lead to affrication, there is no way it could palatalise the consonant.

\subsection{Excursus: What a head needs}

Our discussion so far says nothing about why spreading (preparatory or real) takes place at all. We have identified conditions under which spreading can happen in principle (and will add to this when looking at vowels in section 6), but we do not know why it happens in some languages but not in others. This is a more general question applicable to any phonological process. In Finnish vowel harmony, I spreads to the right (Gibb 1992; Kaye 2001; Pöchtrager 2006a). The Northern varieties of Estonian (hence also the standard), though otherwise similar to Finnish in many respects, have lost vowel harmony (Laanest 1982: 50). Trying to isolate causes for contingent phenomena is a dangerous enterprise; if that the causes cannot be independently motivated we run the risk of circular explanation. The same is true for affrication, and what follows in this subsection is more like a Gedankenexperiment than a real proposal - in order to turn it into a real proposal, more evidence (also from other phenomena besides affrication) will be needed.

We have made the argument that affrication comes about by a control relationship being lost, linked to the spreading of an element I or $\mathbf{U}$. We have also seen that I has a higher propensity to spread than U. But why does the element spread at all? We have noted that affrication only affects coronal stops and not other places of articulation, making the head representing 
coronality, xO, the motor behind spreading. Inspired by Minimalist Syntax (Chomsky 1995), one could then assume that $\mathrm{xO}$ carries a feature that requires checking, at least in languages like Japanese, Brazilian Portuguese and Québec French. That feature would be checked by I in all three languages and additionally by $\mathbf{U}$ in Japanese. Here, "propensity to spread" would be reinterpreted as "aptness to check the feature in question", i.e. it is more common for I to check the feature than $\mathbf{U}$. In order for checking to take place, the element has to move close to the head that carries the feature in need of checking. How close that is would vary by language: In Japanese, I needs to be in the sister to the head: As a result, coronal plosives palatalise and undergo affrication, while fricatives palatalise. In Brazilian Portuguese and Québec French, on the other hand, checking also operates under sisterhood, but only if the sister in question is the complement. This is exactly what we saw in section 4.1. Our generalisation that operations start from the bottom might simply be reinterpreted in terms of the needs of $\mathrm{xO}$. In case there is no element I (or $\mathbf{U}$ ) following, e.g. in the sequence $t a$, control could be seen as the default kicking in. Finally, languages where affrication is not an issue (Spanish) could simply be assumed to lack said feature on $\mathrm{xO}$.

While the sketch in the last paragraph applies to phonology a mechanism that has been helpful in syntax, viz. feature checking, it also imports the same problems that checking in minimalist syntax often suffers from: If features are posited to drive movement (via checking) and movement is then explained only on the basis of the very feature that was set up to explain it in the first place, nothing is won. This is also true for our feature on $\mathrm{xO}$ : There is no independent evidence for it at this point and it is a new addition to the theory of GP that has no parallels (yet). Its implementation would need a whole theory of checking.

While this way of thinking about the problem is somewhat alien to GP, it is exactly the line of reasoning followed in Nevins (2010). Instead of elements, Nevins employs a feature system that is in fact ternary (plus, minus, absent), and the absence of a feature value is what drives assimilation: A plus or minus value needs to be copied from somewhere else in order to provide a valid (interpretable) feature value. This does not translate easily into a privative system like the element calculus of GP, since a phonological object lacking a given element is in no way deficient: German $\ddot{u}$ contains $\mathbf{U}$ and $\mathbf{I}, u$ only $\mathbf{U}$, yet both are fully interpretable (Harris 1996). An exploration of spreading as the result of satisfying the checking needs of a head might also indicate that the phonological primes we have been operating with are too crude and simplistic. But in the long run this idea might be extended and serve as an answer to why phonological processes happen at all, also within GP.

\section{The internal structure of vowels and glides}

\subsection{Openness as size}

Section 3.3 presented arguments that the element A should be replaced by structure. Such a replacement has consequences for consonants as well as vowels, because (old) A was assumed to occur in both (cf. section 3.3 and fn.13). Reinterpreting A as structural allowed us to identify the head $\mathrm{xO}$ as the reason why affrication targets coronals in the languages under consideration, since it provided us with a unique position that the spreading of I could target. We will now look at the vowels acting as triggers.

The most basic question is why only the $\mathbf{I}$ in $i$ triggers affrication, while other front vowels, despite containing I, do not. In an account relying on A, one would have to argue that A somehow blocks the spreading of I. But that would only be yet again another random quirk of that element without much hope for a non-arbitrary explanation. In an account based on a structural reinterpretation of A, however, such a non-arbitrary account comes into reach. With A gone, openness (one of the roles of old A) must be encoded structurally: High vowels (lacking old A) must be smaller than non-high vowels. That reasoning can be carried further, allowing further subdivisions in the latter group, with open and mid-open vowels (old A variably head or non-head) even bigger than close mid-vowels (old A as non-head). More specifically, a nucleus involves up to two heads, $\mathrm{xn}$ and $\mathrm{xN}$, each of which can project up to twice. This parallels the internal structure of onsets in (15), where A was replaced by more structure (an extra head and its projection). (31) gives the resulting gradual difference in size, building on 
Pöchtrager (2020). ${ }^{36} \mathbf{I}$ is consistently associated with the lowest head, following argumentation in the same source. The specifiers of xn are left out for now; we will come back to them in the next section. a. $[\mathrm{i}]$

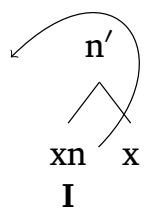

b. $[\mathrm{e}]$

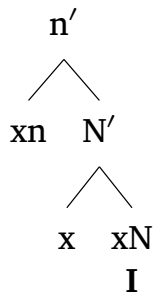
vowel reduction as loss of structure, cf. the characterisation of lenition in (22). ${ }^{37}$ Reduction from $[\varepsilon]$ and [e] (31c, b) to [i] (31a), as in the word-final position in Brazilian Portuguese (Wetzels 1995; Mateus \& d'Andrade 2000), simply involves the loss of $\mathrm{xN}$ and its complete projection, under the assumption that I can escape to the higher head xn to yield [i]. If movement of $\mathbf{I}$ is not allowed in a given language, we predict that the same kind of pruning would lead to the the structure in (31a) but without an element I, which is schwa. This is exactly the reduction pattern we find in Eastern Catalan (Wheeler 2005). Reduction from [c] (31c) to [e] (31b) simply involves the loss of the complement of $x N$ with subsequent adjustment of projection levels. In this case no element has to be moved from $\mathrm{xN}$ to $\mathrm{xn} .{ }^{38}$ Note that yet again all those reductions start from the bottom of the tree, removing positions further down first.

In addition to vowel reduction, the representational format in (31) also provides the means to single out $i$ vs. other front vowels, relevant for affrication. In fact, (31) allows formulating this restriction in two different ways: By depth of embedding and/or by reference to particular heads. Depth of embedding expresses the idea that in order to get out from the head and into a preceding onset, $\mathbf{I}$ has to cover only a short distance in [i] (indicated by the arrow in (31a)), unlike (31b-c), where a longer distance has to be covered. ${ }^{39}$ At the same time, in [i] (31a) I is associated to xn, but in [e] and [e] (31b-c) it is associated to $\mathrm{xN}$. One could simply stipulate that elements in the projection of $\mathrm{xN}$ cannot get out. Whether I fails to get out in (31b-c) only because of the distance or (also) because of its particular location is not completely decidable on the basis of the data we are dealing with here. But for our current purposes nothing hinges on this; we can explain either way why [i] leads to affrication in the languages under discussion here. There is one indication, however, that position is more important, and we will turn to this piece of evidence in the next subsection.

36 The reader is reminded that phonetic symbols like [e] and [ $[\varepsilon]$ are not always used consistently: Read as cardinal vowels, they express a difference purely in openness. At the same time, they are also employed to represent differences in tenseness. The reader is referred to Pöchtrager (2020) for further discussion.

37 Treatments of vowel height as a phonologically scalar property are found as early as Trubetzkoy (1939: 59ff, especially 67); but also in Chen (1973) and Foley (1977), where openness is one (of several) strength scales. But none of those authors assume internal structure in the sense that [e] could be a substructure of $[\varepsilon]$ etc. The same applies to Clements (1991) and his splitting up of [open] into [open ] $_{\text {, [open }}$ ] etc.

38 This deviates minimally from the original proposal in Pöchtrager (2018), but is more in line with the findings in Pöchtrager $(2017 ; 2020)$ and with the argumentation developed here. Vowel reduction is of course more complex and varied than given here, cf. Pöchtrager (2018) for more details.

39 A reviewer inquires why distance should matter for I going up and outside of its nucleus, while it seems to be able to go all the way down into a coronal stop when leading to its affrication. Just as in syntax (e.g. in c-command), the theory assumes that there is a limit in how far things can reach up, but not in how far they can reach down (in principle). Živanovič \& Pöchtrager (2010) apply this to the U-element in Mandarin: $\mathbf{U}$ in $k^{w}$ interacts with a following nucleus (it sits in a high position within the onset), but not in $p$ (where it sits lower down). Pöchtrager (2017) argues that, while both neutral and front vowels in (Finnish) vowel harmony contain I, that element sits in a higher position in front vowels and can thus get out more easily. 


\subsection{Onglides}

The format underlying (31) also provides a position for onglides, viz. the specifier of xn. This is illustrated in (32a), contrasting [ja] (32a) to [i] (32b, repeated from 31a).

a. $[\mathrm{ja}]$

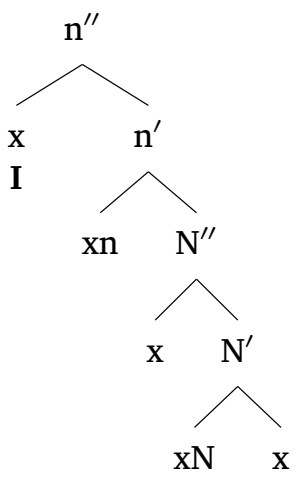

b. [i]

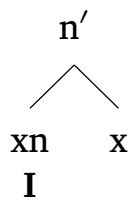

In (32a), I in the specifier of xn gives us the high front glide, while the remaining structure represents the open vowel [a]. ${ }^{40}$ In Japanese, Brazilian Portuguese and Québec French [j], just like its syllabic counterpart, acts as a trigger for affrication and, except for Québec French of course, palatalisation. In order to understand the difference between (32a-b) we need to look at English where only [j] can ever act as a trigger. ${ }^{41}$

$$
\begin{array}{lll}
\text { a. } & \text { We want you } & [\mathrm{t}]+[\mathrm{j}] \rightarrow[\mathrm{t}]] \\
\text { b. } & \text { We miss you } & {[\mathrm{s}]+[\mathrm{j}] \rightarrow[\mathrm{f}]} \\
\text { c. } & \text { We want it } & \text { affrication/palatalisation impossible } \\
\text { d. } & \text { We miss it } & \text { palatalisation impossible }
\end{array}
$$

(33a-b) shows that [j] triggers the same changes in English as in Japanese, but (33a-b) vs. (33c-d) makes clear that only the glide acts as a trigger. That glides are more likely triggers than vowels has been observed often before, cf. Chen (1973: 182) and Bhat (1978: 60, restricting this to apicals). In fact, this observation, too, can derived from (32).

Firstly, the high likelihood of both [j] and [i] to act as triggers is unsurprising, given their high position in the structure, which, as we saw in the previous section, is a (maybe the) crucial factor for whether an element can spread or not. Getting out of the specifier in (32a) means having to cross only a small amount of structure, in fact, the same amount of structure as I has to cover in (32b). By the same token, $\mathbf{I}$ is not contained in the projection of $x N$ in either (32a-b). Secondly: If the amount of structure for I to cross is equal in (32a-b), how come that the glide [j] is more likely to lead to affrication/palatalisation than [i]? The answer must lie in where I spreads out of: Elements in a specifier seem more flexible than elements in the head, hence an (on)glide will be a more likely trigger than a vowel. ${ }^{42}$

Of course this does not imply that elements in specifier positions will always get out, just as an I in a vowel will not spread in every single language. English coronal stops do have an uneasy relation with a following [j], in that some varieties have gotten rid of [j] altogether (tune [tu:n]) or have lexicalised palatalisation/affrication ([t]u:n]), but [tju:n] (where I remains in the specifier of the nucleus) does exist in at least some varieties.

\subsection{A final note on Japanese $u$}

Japanese $u$ is quite unrounded [u] , going towards [u]. One might question whether that vowel is comparable to the $u$-type vowels we find in Québec French and Brazilian Portuguese, i.e. $[\mathrm{u} / \mathrm{v}]$. Previous treatments of Japanese within GP (Yoshida 1996; Backley \& Nasukawa 2020) do assume that $u$ contains $U$, albeit often with a special quirk: Yoshida (1996), to account for the unrounded nature of $u$, assumes that $\mathbf{U}$ is present but unassociated. Given that $u$ can colour

40 For details on onglides within GP 2.0 cf. Živanovič \& Pöchtrager (2010), Pöchtrager (2015).

41 In accordance with the NAP and MH (section 1) I do not take alternations like president/presidency as evidence for a(nother) phonological process of palatalisation.

42 See also fn. 39 for a similar observation on Mandarin U. 
adjacent $h$, as in Fuji [фurdzi]/*[hudzi], it does make sense to assume that the vowel contains $\mathrm{U}$ in its internal structure as an integral part, and not just as a floater. ${ }^{43}$ Furthermore, in the Kansai varieties $u$ is more rounded (Labrune 2012), and still it triggers affrication, suggesting that the exact degree of rounding is immaterial here. And finally, even if Japanese $u$ is treated as somewhat different from "proper" [u], we still need to explain why that vowel triggers affrication at all in the same fashion as Québec French [i] without any obvious spreading of melody. Some relation between the vowel and the preceding consonant has to hold, and, as we have seen, that relation is one of preparatory spreading.

\section{Conclusion}

Before we conclude, let me quickly address two recent contributions within GP that bring up affrication. Nasukawa (2016), in a GP spin-off dubbed precedence-free phonology, deals with affrication in Japanese. The spreading of I plays a central role, as it does here, and Nasukawa links the conditions on spreading to other aspects of Japanese phonology, such as the incompatibility of $\mathbf{I}$ and $\mathbf{U}$ in vowels and consonants. (This is not directly translatable to the present account because his representation of consonantal place differs from mine.) However, affrication is never addressed as such, but simply taken as an automatic consequence of palatalisation without any representational consequence. As a result, other properties that go with affrication (summarised below) are simply not touched upon.

Tifrit \& Voeltzel (2016), in a diachronic account of velar palatalisation in French, take affricates as stops that contain two "portions" of melody, each in different positions within the tree. This would qualify their approach as the "complex segment" type (Lin 2011: 368). I see three problems with that: (i) Since the two bits of melody are independent, we lose the fact that affricates require homorganicity; the same worry as expressed in Clements (1999). (ii) Two separate portions of melody will be problematic in the representation of, say, labiovelars, which also contain two discernible melodic parts, but they are not affricates. (iii) If affricates have two portions of melody and stops only one, that means that stops could be a lenition outcome of affricates, counter to fact.

How is the present account different then? In section 2 five questions were raised with regard to the various asymmetries seen in affrication/palatalisation patterns. Each question was addressed in turn and here I would like to summarise the answers and point out their strengths, also vis-à-vis alternative proposals.

Firstly, in all three languages coronals are singled out by affrication and palatalisation. Many theories assume that coronals are simpler, more unmarked or underspecified in some way. The present theory follows a two-pronged approach, so to speak, in that they are melodically simple but structurally rich: Coronals are unmarked in the sense that they do not contain any elements but are pure structure. In that respect they are similar to velars, which also lack melody (but are substantially smaller). At the same time, coronals have rich internal structure (more precisely an additional head $\mathrm{xO}$ ), which is the reason why they are targeted by lenition to begin with. This is true for affrication as well as tapping and glottaling, where the varying outcomes are simply simplifications of the original consonant.

Making coronals big might be even more counterintuitive when looking at neutralisation patterns where coronals are outcomes, or at cases of assimilation with coronals as typical undergoers, both pointing in the direction of their unmarkedness. But clearly, neutralisation does not necessarily imply that some property is lost, only that differences are levelled out. As the discussion of Korean has shown, the big size of coronals, in particular coronal stops, does not prevent them from being neutralisation outcomes. To the extent that we understand where any extra structure that is possibly required comes from, the resulting analysis is only improved. In the case of Korean we could not only explain neutralisation but also how it is connected to its environment (a nucleus that needs silencing). Similarly, proneness to assimilation does not require coronals to be simple or underspecified. In Korean $\mathrm{C}_{1} \mathrm{C}_{2}$ obstruent sequences coronals assimilate to a following labial or velar, while labials only assimilate to velars, and velars do not

43 Yoshida leaves open the question how $\mathbf{U}$ gets interpreted or in what way it is linked to a particular (instead of just any) nucleus and still floating (and thus not linked by definition), making the whole concept suspicious. 
assimilate at all (Hume 2003: 300). Heo (1994), in earlier version of GP, argued that $C_{2}$ governs $\mathrm{C}_{1}$ in $\mathrm{C}_{1} \mathrm{C}_{2}$, which requires $\mathrm{C}_{1}$ to be no more complex than $\mathrm{C}_{2}$. Reinterpreted in our terms: Coronals in $\mathrm{C}_{1}$ undergo assimilation exactly because they are the biggest, not because they are the simplest. The required complexity differential leads to trees being cut to size. Coronals being the biggest, they will always fall prey to assimilation, while velars are the simplest (in terms of place) and thus do not assimilate. Note that reference to the unmarkedness of coronals cannot be the complete story, anyway, since labials sit in the middle between velars and labials and also assimilate (to velars). Given that a labial differs from a velar by the presence of an $\mathbf{U}$ in the former (and no counterpart in the latter), we establish yet again a difference in complexity, only that this time melody is the crucial difference. This is exactly the same difference we had assumed for English in section 4.2.

In fact, the rich structure of coronals leads us to expect that if such rich structure is found elsewhere, we should expect similar outcomes, thus allowing us to capture generalisations that go beyond coronals proper. This is borne out: Openness in vowels is also expressed by richer structure, in fact by the same kind of richer structure, and again it is this extra structure that is targeted by lenition (vowel reduction). This account allows us to reinterpret qualitative reduction (section 6.1) as structural and thereby to put it on a par with structural simplifications, such as loss of vowel length in unstressed position. ${ }^{44}$

So is this just old wine in new bottles? No; I would argue we have done much more than that. While it is true that we have simply exchanged and old element (A) by structure, this new representation is more adequate in that it captures better the various quirks we see associated with coronality/non-high vowels. As discussed in section 3.3, many of those quirks have to do with purely structural properties, like the distribution of long vowels before clusters etc. Only by making A structural can such a relationship be captured. This goes way beyond what an element $\mathbf{A}$ or a feature [coronal] could achieve.

The second question addressed the hierarchy whereby high vowels and glides trigger affrication/palatalisation, while that ability peters out in mid and low vowels. While wellestablished in typological work (section 1 for references), this observation does not really figure very prominently in many accounts, which usually focus on the contribution of frontness. Palatalisation as such can of course easily be explained as the spreading of the (frontness) element I. The problem is that that element is present in other front vowels, too, so where does the hierarchy come from? As we saw in section 6.1, the present theory assumes that openness is a scalar property expressed by size in order to model vowel reduction. As as side-effect, this leads to I being more accessible in high vowels, less so in close-mid vowels and least in open (-mid) vowels, which is exactly what we need for the hierarchy of palatalisation potency. This extends naturally to glides, whose high position in the tree makes them even better triggers than high vowels. Yet again, an analytical choice for one problem (reduction) helps us to understand another one (palatalisation).

As for the difference between affricates, stops, and fricatives (the third question): Affricates group with fricatives in that both lack a control relationship, while affricates and stops align in that both have a complement position. Affricates thus stand in the middle by having a(n empty) complement that is uncontrolled. This allows us to express a natural link between affrication and palatalisation (the fourth question): We know that palatalisation is simply the spreading of I; and by I spreading into a complement position the control relationship defining a stop is lost, leading to affrication as a natural outcome. The operation to model a commonly observed phenomenon is formally very simple and non-arbitrary. More importantly, most of the tools needed had already been in place prior to this analysis of affricates. The missing link was a proper understanding of control, which has been provided here. No repair, like tier-promotion in Clements \& Hume (1995), is required.

44 A reviewer points out that making openness about size also seems to imply that bigger size means more sonority, which would conflict with stops being bigger (yet less sonorous) than fricatives. It is not my intention to give a measure of sonority, and I agree with the criticism expressed against it in Harris (2006; 2009). The complexity of phonological objects, both in size and in terms of elements, corresponds more closely to the information content in the signal, understood as a deviation from a neutral baseline (an old idea in GP: Harris \& Lindsey 1995; 2000; Williams 1998; Harris 2009; Backley 2011). This motivates the modelling of lenition as a loss of phonological material, cf. (22). A similar comment has to be made about the problematic notion of markedness; for recent discussion cf. the contributions in Samuels (2017). 
A further difference between stops and fricatives, viz. that the former undergo a change in manner (affrication) and palatalisation while the latter only palatalise, also follows from our representations. Since fricatives have no control relationship by definition, a change in manner is neither expected nor possible. As Krämer \& Urek (2016: 10f) rightly criticise, this is usually handled by various repair mechanisms (redundancy rules) in other accounts. Note in this context that control is not some diacritic, but has obvious (acoustic) consequences: It keeps the complement silent. As such, it is identified as part of a set of tools to silence empty positions under the regulation of the phonological ECP (Charette 1991; Kaye 1995).

Differences between languages in the outcomes of affrication/palatalisation are captured in two ways. One the one hand by reference to structural differences that are required in any case, such as the specifier/complement asymmetry. This allows for a simple account of the difference between Brazilian Portuguese and Japanese when it comes to the palatalisation of $s$ (section 4.3). On the other hand, Québec French showed affrication without any obvious sign of spreading of I. This dissociation was captured by a notion dubbed preparatory spreading, which indicates that there is a relationship like spreading only without actual transferral of melody. It is treated as a kind of spreading because there are tangible consequences such as the removal of a control relationship and because we see the same asymmetries between the spreading of I and $\mathbf{U}$ that we see elsewhere, which brings us to the final topic.

Fifth and last question: Front vowels/glides are more likely to trigger affrication than back vowels; again a well-established observation in the literature. The primes characterising the two sets, I and $\mathbf{U}$, have shown asymmetric behaviour elsewhere as well, most notably in vowel harmony, cf. section 5.2 and references there. That asymmetry concerned the propensity to spread, with I showing more flexibility than U. For the time being this difference does not seem to be derivable from higher principles, but it is reassuring that the same asymmetry comes back in affrication, where it is responsible for the the back/front asymmetry noted. It seems unwise not to see these two phenomena as reflections of the same underlying principle.

The strength of this proposal then is not that it uncovers new facts about well-studied languages. It is not a typological study and does not intend to be one or to replace them. Instead, it tries to connect a number of ideas about phonological structure from which, when put together, we can derive a number of characteristics that we find in intricate phenomena like affrication and palatalisation and that previously might have appeared unconnected. Those characteristics are given their proper place within phonological theory.

\section{Competing interests}

The author has no competing interests to declare.

\section{Author affiliation}

Markus A. Pöchtrager (D) orcid.org/0000-0002-8743-8165

University of Vienna, Sensengasse 3a, 1090 Vienna, Austria

\section{References}

Anderson, John \& Colin J. Ewen. 1987. Principles of Dependency Phonology. Cambridge: Cambridge University Press. DOI: $h$ ttps://doi.org/10.1017/CBO9780511753442

Backley, Phillip. 2011. An Introduction to Element Theory. Edinburgh: Edinburgh University Press.

Backley, Phillip \& Kuniya Nasukawa. 2020. Conditions on the variable interpretation of $|\mathrm{U}|$ in Japanese. Linguistic Variation 20(1). 84-101. DOI: https://doi.org/10.1075/lv.16012.bac

Balc1, Ercan. 2006. A Government Phonology Analysis of Turkish Consonants. İstanbul: Boğaziçi University dissertation.

Bateman, Nicoleta. 2007. A Crosslinguistic Investigation of Palatalization. San Diego, CA: University of California dissertation.

Bateman, Nicoleta. 2011. On the typology of palatalization. Language and Linguistics Compass 5(8). 588602. DOI: $h$ ttps://doi.org/10.1111/j.1749-818X.2011.00294.x

Bayer, Josef. 2006. Wh-in-situ. In Martin Everaert \& Henk van Riemsdijk (eds.), The Blackwell Companion to Syntax, 376-438. Hoboken, NJ: Wiley/Blackwell. DOI: https://doi.org/10.1002/9780470996591. $\operatorname{ch} 77$ 
Bhat, D. N. S. 1978. A general study of palatalization. In Greenberg et al. (1978) 47-92.

Broadbent, Judith M. 1991. Linking and Intrusive r in English. UCL Working Papers in Linguistics 3. 281301.

Broadbent, Judith M. 1999. A new approach to the representation of coronal segments. In S. J. Hannahs \& Mike Davenport (eds.), Issues in Phonological Structure. Papers from an International Workshop, 1-25. Amsterdam/Philadelphia: John Benjamins. DOI: https://doi.org/10.1075/cilt.196.04bro

Chang, Suk-Jin. 1996. Korean. Amsterdam: John Benjamins.

Charette, Monik. 1990. Licence to govern. Phonology 7. 233-253. DOI: https://doi.org/10.1017/ S0952675700001196

Charette, Monik. 1991. Conditions on phonological government. Cambridge et al.: Cambridge University Press. DOI: https://doi.org/10.1017/CBO9780511554339

Charette, Monik \& Aslı Göksel. 1994. Vowel Harmony and Switching in Turkic languages. SOAS Working Papers in Linguistics \& Phonetics 4. 29-56.

Charette, Monik \& Aslı Göksel. 1996. Licensing constraints and vowel harmony in Turkic languages. SOAS Working Papers in Linguistics \& Phonetics 6. 1-25.

Chen, Matthew. 1973. Predictive power in phonological description. Lingua 32. 173-191. DOI: https://doi. org/10.1016/0024-3841(73)90041-7

Chen, Su-I. 1996. A theory of palatalization and segment implementation. Stony Brook, NY: State University of New York dissertation.

Cheng, Lisa Lai-Shen. 2003a. Wh-in-situ. Glot International 7(4). 103-109.

Cheng, Lisa Lai-Shen. 2003b. Wh-in-situ, Part II. Glot International 7(5). 129-137.

Chomsky, Noam. 1964. Current Issues in Linguistic Theory. London, The Hague, Paris: Mouton \& Co.

Chomsky, Noam. 1995. The Minimalist Program. Cambridge, Mass. \& London, UK: MIT Press.

Chomsky, Noam \& Morris Halle. 1968. The Sound Pattern of English. New York, Evanston, London: Harper \& Row.

Clements, George N. 1991. Vowel Height Assimilation in Bantu Languages. Working Papers of the Cornell Phonetics Laboratory 5. 37-76.

Clements, George N. 1999. Affricates as Noncontoured Stops. In Osamu Fujimura, Brian D. Joseph \& Bohumil Palek (eds.), Proceedings of LP '98: Item Order in Language and Speech, 271-299. Prague: The Karolinum Press.

Clements, George N. \& Elizabeth V. Hume. 1995. The Internal Organization of Speech Sounds. In John A. Goldsmith (ed.), The Handbook of Phonological Theory, 245-306. Cambridge, Mass. \& Oxford: Blackwell.

Cobb, Margaret. 1995. Vowel Harmony in Zulu and Basque: The Interaction of Licensing Constraints, H-Licensing and Constituent Structure. SOAS Working Papers in Linguistics \& Phonetics 5. 23-39.

Cobb, Margaret. 1997. Conditions on Nuclear Expressions in Phonology. London, UK: School of Oriental and African Studies, University of London dissertation.

Cristófaro-Silva, Thaïs. 2003. Palatalisation in Brazilian Portuguese. In Stefan Ploch (ed.), Living on the Edge. 28 Papers in Honour of Jonathan Kaye, 243-257. Berlin \& New York: Mouton de Gruyter. DOI: https://doi.org/10.1515/9783110890563.243

Crothers, John. 1978. Typology and Universals of Vowel Systems. In Greenberg et al. (1978) 93-152.

Cyran, Eugeniusz. 1997. Resonance Elements in Phonology. A Study in Munster Irish. Lublin: Wydawnictwo Folium.

Denwood, Ann. 1997. The Role of the Element I in Khalkha Mongolian Phonology. London: School of Oriental and African Studies, University of London dissertation.

Dressler, Wolfgang U. 1972. Allegroregeln rechtfertigen Lentoregeln. Sekundäre Phoneme des Bretonischen. Innsbruck: Universität Innsbruck.

Dressler, Wolfgang U. 1985. Morphonology: the dynamics of derivation. Ann Arbor: Karoma Publishers Inc.

Durand, Jacques \& Francis Katamba (eds.). 1995. Frontiers of phonology: Atoms, structures, derivations. London, New York: Longman.

Dziubalska-Kołaczyk, Katarzyna (ed.). 2001. Constraints and Preferences. Berlin, New York: Mouton de Gruyter. DOI: https://doi.org/10.1515/9783110881066

Erguvanlı Taylan, Eser. 2015. The Phonology and Morphology of Turkish. Istanbul: Boğaziçi University Press.

Foley, James. 1977. Foundations of theoretical phonology. Cambridge, London, New York, Melbourne: Cambridge University Press.

Fox, Anthony. 2000. Prosodic Features and Prosodic Structure. The Phonology of Suprasegmentals. Oxford: Oxford University Press.

Fox, Danny. 2003. On Logical Form. In Randall Hendrick (ed.), Minimalist Syntax, 82-123. Oxford: Blackwell. DOI: https://doi.org/10.1002/9780470758342.ch2

Fudge, Erik C. 1969. Syllables. Journal of Linguistics 5. 253-286. DOI: https://doi.org/10.1017/ S0022226700002267 
Gibb, Lorna. 1992. Domains in phonology: With evidence from Icelandic, Finnish \& Kikuyu. Edinburgh: University of Edinburgh dissertation.

Goad, Heather. 2011. The Representation of sC Clusters. In Marc van Oostendorp, Colin J. Ewen, Elizabeth Hume \& Keren Rice (eds.), The Blackwell Companion to Phonology 2. 898-923. Hoboken, NJ: Wiley/Blackwell.

Goh, Yeng-Seng. 1997. The Segmental Phonology of Beijing Mandarin. Crane Publishing Co., Ltd: Taipei.

Göksel, Aslı \& Celia Kerslake. 2005. Turkish: A Comprehensive Grammar. London, New York: Routledge. DOI: https://doi.org/10.4324/9780203340769

Goldsmith, John A. 1976. Autosegmental Phonology. Bloomington, Indiana: Indiana University Linguistics Club.

Greenberg, Joseph H., Charles A. Ferguson \& Edith A. Moravcsik (eds.). 1978. Universals of Human Language. Volume 2: Phonology. Stanford: Stanford University Press.

Gussmann, Edmund. 2007. The Phonology of Polish. Oxford: Oxford University Press.

Hall, Tracy Alan \& Silke Hamann. 2006. Towards a typology of stop assibilation. Linguistics 44(6). 11951236. DOI: https://doi.org/10.1515/LING.2006.039

Halle, Morris. 1959. The Sound Pattern of Russian. A Linguistic and Acoustical Investigation. The Hague: Mouton.

Halle, Morris \& Jean-Roger Vergnaud. 1980. Three dimensional phonology. Journal of Linguistic Research 1(1). 83-105.

Harlow, Ray. 2007. Māori. A Linguistic Introduction. Cambridge: Cambridge University Press. DOI: https:// doi.org/10.1017/CBO9780511618697

Harris, John. 1990. Segmental complexity and phonological government. Phonology 7(2). 255-301. DOI: https://doi.org/10.1017/S0952675700001202

Harris, John. 1994. English Sound Structure. Oxford et al.: Blackwell.

Harris, John. 1996. Phonological Output is Redundancy-free and Fully Interpretable. In Jacques Durand \& Bernard Laks (eds.), Current Trends in Phonology: Models and Methods I. 305-332. Salford, Manchester: European Studies Research Institute (ESRI).

Harris, John. 1997. Licensing Inheritance: an integrated theory of neutralisation. Phonology 14. 315-370. DOI: https://doi.org/10.1017/S0952675798003479

Harris, John. 1999. Release the captive coda: the foot as a domain of phonetic interpretation. UCL Working Papers in Linguistics 11. 165-194.

Harris, John. 2006. The phonology of being understood: Further arguments against sonority. Lingua 116. 1483-1494. DOI: https://doi.org/10.1016/j.lingua.2005.07.009

Harris, John. 2009. Why final obstruent devoicing is weakening. In Kuniya Nasukawa \& Phillip Backley (eds.), Strength Relations in Phonology, 9-45. Berlin, New York: Mouton de Gruyter. DOI: https://doi. org/10.1515/9783110218596.1.9

Harris, John \& Edmund Gussmann. 1998. Final codas: why the west was wrong. In Eugeniusz Cyran (ed.), Structure and Interpretation. Studies in Phonology (PASE Studies and Monographs. 4), 139-162. Lublin: Wydawnictwo Folium.

Harris, John \& Geoff Lindsey. 1995. The elements of phonological representation. In Durand \& Katamba (1995) 34-79.

Harris, John \& Geoff Lindsey. 2000. Vowel patterns in mind and sound. In Noel Burton-Roberts, Philip Carr \& Gerry Docherty (eds.), Phonological knowledge: conceptual and empirical issues, 185-205. Oxford: Oxford University Press.

Harris, John \& Jonathan Kaye. 1990. A tale of two cities: London Glottaling and New York City Tapping. The Linguistic Review 7(3). 251-274. DOI: https://doi.org/10.1515/tlir.1990.7.3.251

Heo, Yong. 1994. Empty Categories and Korean Phonology. London: School of Oriental and African Studies, University of London dissertation.

Hume, Elizabeth. 2003. Language specific markedness: the case of place of articulation. Studies in Phonetics, Phonology and Morphology 9(2). 295-310.

Jensen, Sean. 1994. Is 2 an Element? Towards a Non-segmental Phonology. SOAS Working Papers in Linguistics \& Phonetics 4. 71-78.

Kaun, Abigail Rhoades. 1995. The Typology of Rounding Harmony: An Optimality Theoretic Approach. Los Angeles, CA: University of California dissertation.

Kaye, Jonathan. 1989. Phonology: A Cognitive View. Hillsdale, NJ: Lawrence Erlbaum.

Kaye, Jonathan. 1990a. 'Coda' Licensing. Phonology 7(2). 301-330. DOI: https://doi.org/10.1017/ S0952675700001214

Kaye, Jonathan. 1990b. Government in Phonology. The Case of Moroccan Arabic. The Linguistic Review 6. 131-159. DOI: https://doi.org/10.1515/tlir.1987.6.2.131

Kaye, Jonathan. 1992a. Do you believe in magic? The story of $s+C$ sequences. SOAS Working Papers in Linguistics \& Phonetics 2. 293-313. 
Kaye, Jonathan. 1992b. On the interaction of theories of Lexical Phonology and theories of phonological phenomena. In Wolfgang U. Dressler, Hans C. Luschützky, Oskar E. Pfeiffer \& John R. Rennison (eds.), Phonologica 1988. Proceedings of the 6th International Phonology Meeting, 141-155. Cambridge et al.: Cambridge University Press.

Kaye, Jonathan. 1995. Derivations and interfaces. In Durand \& Katamba (1995) 289-332.

Kaye, Jonathan. 2000. A User's Guide to Government Phonology (GP). Ms.

Kaye, Jonathan. 2001. Working with licensing constraints. In Dziubalska-Kołaczyk (2001) 251-268.

Kaye, Jonathan, Jean Lowenstamm \& Jean-Roger Vergnaud. 1985. The internal structure of phonological elements: a theory of charm and government. Phonology Yearbook 2. 303-328. DOI: https://doi. org/10.1017/S0952675700000476

Kaye, Jonathan, Jean Lowenstamm \& Jean-Roger Vergnaud. 1990. Constituent structure and government in phonology. Phonology 7(2). 193-231. DOI: https://doi.org/10.1017/S0952675700001184

Kaye, Jonathan \& Markus A. Pöchtrager. 2009. GP 2.0. Paper presented at the "Government Phonology Round Table", April 25, 2009, Piliscsaba/Hungary.

Kaye, Jonathan \& Markus A. Pöchtrager. 2013. GP 2.0. SOAS Working Papers in Linguistics \& Phonetics 16. 51-64.

Kehrein, Wolfgang. 2002. Phonological Representation and Phonetic Phasing. Affricates and Laryngeals. Tübingen: Max Niemeyer Verlag. DOI: https://doi.org/10.1515/9783110911633

Kim, Hyunsoon. 1997. The phonological representation of affricates: Evidence from Korean and other languages. Ithaca, NY: Cornell University dissertation.

Kim, Hyunsoon. 1999. The place of articulation of Korean affricates revisited. Journal of East Asian Linguistics 8. 313-347. DOI: https://doi.org/10.1023/A:1008331010694

Kim, Hyunsoon. 2001. A phonetically based account of phonological stop assibilation. Phonology 18. 81-108. DOI: https://doi.org/10.1017/S095267570100402X

Kim, Seon Jung. 1996. The Representations of Korean Phonological Expressions and Their Consequences. London: School of Oriental and African Studies, University of London dissertation.

Kiparsky, Paul. 1976. Abstractness, Opacity, and Global Rules. In Andreas Koutsoudas (ed.), The Application and Ordering of Grammatical Rules, 160-184. The Hague, Paris: Mouton.

Kiparsky, Paul. 1985. Some Consequences of Lexical Phonology. Phonology Yearbook 2. 85-138. DOI: https://doi.org/10.1017/S0952675700000397

Kiparsky, Paul. 1993. Blocking in Nonderived Environments. In Sharon Hargus \& Ellen M. Kaisse (eds.), Phonetics and Phonology. Volume 4. Studies in Lexical Phonology, 277-313. San Diego et al.: Academic Press. DOI: https://doi.org/10.1016/B978-0-12-325071-1.50016-9

Kochetov, Alexei. 2002. Production, Perception, and Phonotactic Patterns: A Case of Contrastive Palatalization. London, New York: Routledge.

Kochetov, Alexei. 2011. Palatalization. In Marc van Oostendorp, Colin J. Ewen, Elizabeth Hume \& Keren Rice (eds.), The Blackwell Companion to Phonology 3. 1666-1690. Hoboken, NJ: Wiley/Blackwell. DOI: https://doi.org/10.1002/9781444335262.wbctp0071

Kopkall, Handan. 1993. A phonetic and phonological analysis of final devoicing in Turkish. Ann Arbor, MI: University of Michigan dissertation.

Krämer, Martin. 2009. The Phonology of Italian. Oxford: Oxford University Press.

Krämer, Martin \& Olga Urek. 2016. Perspectives on palatalization. Glossa 1(1)(31). 1-17. DOI: https://doi. org/10.5334/gigl.26

Laalo, Klaus. 1988. Imperfektimuotojen ti $\sim$ si-vaihtelu suomen kielessä. [The ti $\sim$ si alternation of imperfect forms in Finnish]. Helsinki: Suomalaisen Kirjallisuuden Seura.

Laanest, Arvo. 1982. Einführung in die ostseefinnischen Sprachen. Hamburg: Buske. Transl. Hans-Hermann Bartens.

Labrune, Laurence. 2012. The Phonology of Japanese. Oxford: Oxford University Press. DOI: https://doi. org/10.1093/acprof:oso/9780199545834.001.0001

LaCharité, Darlene. 1993. The Internal Structure of Affricates. Ottawa: University of Ottawa dissertation.

Lahiri, Aditi \& Vincent Evers. 1991. Palatalization and Coronality. In Paradis \& Prunet (1991) 79-100. DOI: https://doi.org/10.1016/B978-0-12-544966-3.50011-7

Larsen, Uffe Bergeton. 1994. Some Aspects of Vowel Length and Stød in Modern Danish. Paris: Université Paris 7 MA thesis.

Lee, Hyun Bok. 1999. Korean. In Handbook of the International Phonetic Association. A guide to the use of the International Phonetic Alphabet, 120-123. Cambridge: Cambridge University Press.

Lees, Robert B. 1961. The Phonology of Modern Standard Turkish. Bloomington: Indiana University.

Lewis, Geoffrey. 1967. Turkish Grammar. Oxford: Oxford University Press.

Lin, Yen-Hwei. 2011. Affricates. In Marc van Oostendorp, Colin J. Ewen, Elizabeth Hume \& Keren Rice (eds.), The Blackwell Companion to Phonology 1. 367-390. Hoboken, NJ: Wiley/Blackwell.

Mateus, Maria Helena \& Ernesto d'Andrade. 2000. The Phonology of Portuguese. Oxford: Oxford University Press. 
May, Robert. 1977. The grammar of quantification. Cambridge, MA: MIT dissertation.

May, Robert. 1985. Logical Form: Its Structure and Derivation. Cambridge, MA: The MIT Press.

Mutlu, Filiz. 2017. Valence and Saturation in Phonology. İstanbul: Boğaziçi University MA thesis.

Nasukawa, Kuniya. 2016. A precedence-free approach to (de-)palatalisation in japanese. Glossa 1(1)(9). 1-21. DOI: https://doi.org/10.5334/gjgl.26

Nevins, Andrew. 2010. Locality in Vowel Harmony. Cambridge, Mass. \& London, England: MIT Press. DOI: https://doi.org/10.7551/mitpress/9780262140973.001.0001

Paradis, Carole \& Jean-François Prunet (eds.). 1991. Phonetics and Phonology. Volume 2: The Special Status of Coronals: Internal and External Evidence. San Diego: Academic Press.

Pesetsky, David. 2000. Phrasal Movement and its Kin. Cambridge, MA: The MIT Press. DOI: https://doi. org/10.7551/mitpress/5365.001.0001

Pintér, Gábor. 2015. The emergence of new consonant contrasts. In Haruo Kubozono (ed.), Handbook of Japanese Phonetics and Phonology, 121-165. Berlin: Mouton de Gruyter.

Pöchtrager, Markus A. 2006a. A short note on Finnish diphthongs. In Mickael Suominen \& al. (eds.), A Man of Measure. Festschrift in Honour of Fred Karlsson on his 60th Birthday, 162-171. Turku: The Linguistic Association of Finland.

Pöchtrager, Markus A. 2006b. The Structure of Length. Vienna: University of Vienna dissertation.

Pöchtrager, Markus A. 2010a. Does Turkish Diss Harmony? Acta Linguistica Hungarica 57(4). 458-473. DOI: https://doi.org/10.1556/ALing.57.2010.4.7

Pöchtrager, Markus A. 2010b. The Structure of A. Paper presented at the "33rd GLOW Colloquium", 13-16 April 2010, Wrocław, Poland.

Pöchtrager, Markus A. 2012. Deconstructing A. Paper presented at the "MFM Fringe Meeting on Segmental Architecture”, 23 May 2012, University of Manchester, UK.

Pöchtrager, Markus A. 2013. On A. Paper presented at the "A Workshop on Melodic Representation", 12 March 2013, UCL, London.

Pöchtrager, Markus A. 2014. Alternations: The Vipers in Our Bosom. Dilbilim Araşturmaları Special Number/2. 147-164.

Pöchtrager, Markus A. 2015. Binding in Phonology. In Henk van Riemsdijk \& Marc van Oostendorp (eds.), Representing Structure in Phonology and Syntax, 255-275. Berlin: Mouton de Gruyter. DOI: https://doi.org/10.1515/9781501502224-011

Pöchtrager, Markus A. 2016. It's all about size. In Péter Szigetvári (ed.), 70 snippets to mark Ádám Nádasdy's 70th birthday, http://seas3.elte.hu/nadasdy70/pochtrager.html.

Pöchtrager, Markus A. 2017. Transparent vowels: Small cogs in large machines. Paper presented at the "25th Manchester Phonology Meeting", 25-27 May 2017, University of Manchester, UK.

Pöchtrager, Markus A. 2018. Sawing off the branch you are sitting on. Acta Linguistica Academica 65(1). 47-68. DOI: https://doi.org/10.1556/2062.2018.65.1.3

Pöchtrager, Markus A. 2020. Tense? (re)lax! a new formalisation for a controversial contrast. Acta Linguistica Academica 67(1). 53-71. DOI: https://doi.org/10.1556/2062.2020.00005

Pöchtrager, Markus A. \& Jonathan Kaye. 2011. What is this thing called Phonology? Talk given at the Leiden University Center for Linguistics, Leiden University, November 25, 2011.

Polgárdi, Krisztina. 1998. Vowel Harmony. An Account in Terms of Government and Optimality. The Hague: Holland Academic Graphics.

Polgárdi, Krisztina \& Peter Rebrus. 1998. There is no labial harmony in Hungarian: a government phonology analysis. Approaches to Hungarian 6. 5-20.

Rubach, Jerzy. 1994. Affricates as strident stops in Polish. Linguistic Inquiry 25. 119-143.

Sagey, Elizabeth. 1990. The representation of features and relations in non-linear phonology. New York: Garland Press.

Samuels, Bridget D. 2017. Beyond Markedness in Formal Phonology. Amsterdam/Philadelphia: John Benjamins. DOI: https://doi.org/10.1075/la.241

Schane, Sanford A. 1984. The fundamentals of particle phonology. Phonology Yearbook 1. 129-155. DOI: https://doi.org/10.1017/S0952675700000324

Scheer, Tobias. 2003. Von kölnischer Gutturalisierung, virtuellen Geminaten und ambisilbischen Konsonanten. Ms, University of Nice.

Ségéral, Philippe \& Tobias Scheer. 2001. Abstractness in phonology: the case of virtual geminates. In Dziubalska-Kołaczyk (2001) 311-337.

Selkirk, Elisabeth O. 1982. The Syllable. In Harry van der Hulst \& Norval Smith (eds.), The structure of phonological representations II. 337-383. Dordrecht/Cinnaminson: Foris Publications.

Shin, Jiyoung, Jieun Kiaer \& Jaeeun Cha. 2013. The Sounds of Korean. Cambridge: Cambridge University Press. DOI: https://doi.org/10.1017/CBO9781139342858

Sohn, Ho-Min. 1999. The Korean Language. Cambridge: Cambridge University Press.

Song, Jae Jung. 2005. The Korean Language. Structure, use and context. London, New York: Routledge. DOI: https://doi.org/10.4324/9780203390825 
Taylor, Charles. 1985. Nkore-Kiga. London, Sydney, Dover NH: Croom Helm.

Tifrit, Ali \& Laurence Voeltzel. 2016. Revis(it)ing French palatalization. Glossa 1(1), 10. DOI: https://doi. org/10.5334/gigl.55

Trubetzkoy, N. S. 1939. Grundzüge der Phonologie. Göttingen: Vandenhoeck \& Ruprecht.

Underhill, Robert. 1976. Turkish Grammar. Cambridge, Massachusetts \& London: MIT Press.

van der Hulst, Harry. 1984. Syllable structure and stress in Dutch. Dordrecht: Foris. DOI: https://doi. org/10.1515/9783112419984

van der Hulst, Harry. 1985. Ambisyllabicity in Dutch. In Hans Bennis \& Frits Beukema (eds.), Linguistics in the Netherlands 1985, 57-67. Dordrecht: Foris. DOI: https://doi.org/10.1515/9783112330128-009

van der Torre, Erik Jan. 2003. Dutch sonorants. The role of place of articulation in phonotactics. Leiden: Universiteit Leiden dissertation.

Walker, Douglas C. 1984. The Pronunciation of Canadian French. Ottawa: University of Ottawa Press.

Wetzels, W. Leo. 1995. Mid-vowel alternations in the Brazilian Portuguese verb. Phonology 12(2). 281304. DOI: https://doi.org/10.1017/S0952675700002505

Wheeler, Max W. 2005. The Phonology of Catalan. Oxford, New York: Oxford University Press.

Williams, Geoffrey. 1998. The Phonological Basis of Speech Recognition. London: School of Oriental \& African Studies, University of London dissertation.

Yoshida, Shohei. 1996. Phonological Government in Japanese. Canberra: The Australian National University.

Yoshida, Shohei. 2001. An Element-Based Analysis of Affrication in Japanese. In Jeroen van de Weijer \& Nishihara Tetsuo (eds.), Issues in Japanese Phonology and Morphology, 193-214. Berlin: de Gruyter. DOI: https://doi.org/10.1515/9783110885989.193

Žirmunskij, Viktor Maksimovič. 1962. Deutsche Mundartkunde: vergleichende Laut- und Formenlehre der deutschen Mundarten. Berlin: Akademie-Verlag.

Živanovič, Sašo. 2018. Life without $\mathrm{P}$ and A and what it tells us about branching onsets. Paper presented at “Elements. State of the Art and Perspectives", 14-15 June 2018, University of Nantes, France.

Živanovič, Sašo \& Markus A. Pöchtrager. 2010. GP 2.0 and Putonghua, too. Acta Linguistica Hungarica 57(4). 357-380. DOI: https://doi.org/10.1556/ALing.57.2010.4.1
TO CITE THIS ARTICLE:

Pöchtrager, Markus A. 2021.

Towards a non-arbitrary account of affricates and affrication. Glossa: a journal of general linguistics 6(1): 61. 1-31. DOI: https://doi. org/10.5334/gjgl.1116

Submitted: 30 September 2019 Accepted: 07 October 2020 Published: 07 May 2021

\section{COPYRIGHT:}

(c) 2021 The Author(s). This is an open-access article distributed under the terms of the Creative Commons Attribution 4.0 International License (CC-BY 4.0), which permits unrestricted use, distribution, and reproduction in any medium, provided the original author and source are credited. See http:// creativecommons.org/ licenses/by/4.0/.

Glossa: a journal of general linguistics is a peer-reviewed open access journal published by Ubiquity Press. 